MA Fashion Major Research Project

\title{
Emerging Ghanaian and Nigerian Fashion Entrepreneurs: The Cultural Considerations and Structural Challenges of Growing a Fashion Business in a Developing Economy
}

\author{
ANNIKA WADDELL \\ Supervisor: Dr. Irene Gammel \\ Second Reader: Dr. Alison Matthews David \\ Yeates School of Graduate Studies \\ Ryerson University \\ Toronto, Ontario, Canada
}

May 1, 2017 


\section{AUTHOR'S DECLARATION FOR ELECTRONIC SUBMISSION OF A THESIS}

I hereby declare that I am the sole author of this thesis. This is a true copy of the thesis, including any required final revisions, as accepted by my examiners. I authorize Ryerson University to lend this thesis to other institutions or individuals for the purpose of scholarly research. I further authorize Ryerson University to reproduce this thesis by photocopying or by other means, in total or in part, at the request of other institutions or individuals for the purpose of scholarly research. I understand that my thesis may be made electronically available to the public. 


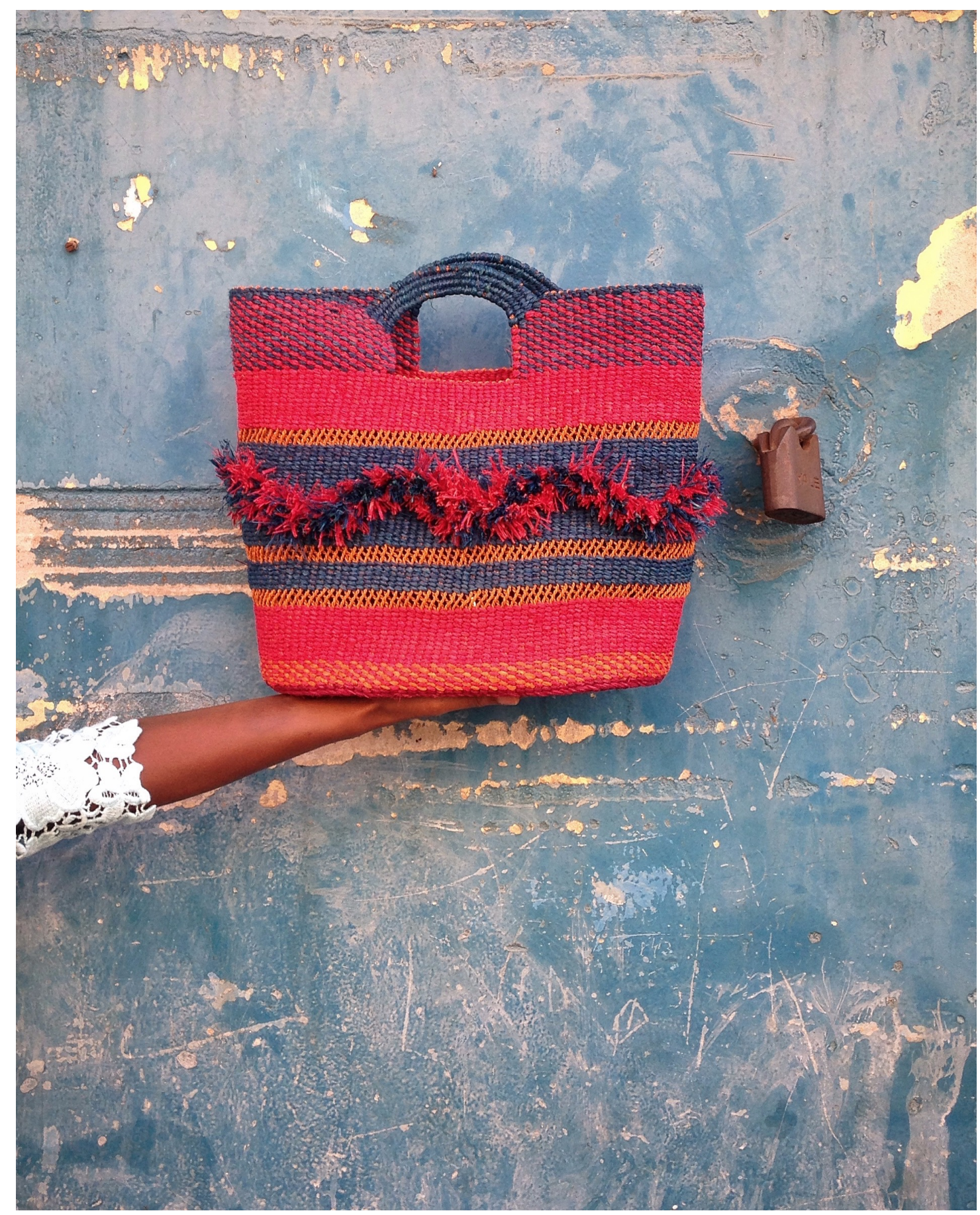

Akosua Afriyie-Kumi Creative Director of AAKS holding a bag titled "Gore." Photograph by AAKS. 2016. Photo Courtesy of AAKS. 


\section{Table of Contents}

Author's Declaration 2

African Fashion Terminology $\quad 5$

List of Participants, A-Z 6

$\begin{array}{ll}\text { Introduction } & 7\end{array}$

1 / Toward a Method for Studying Africa's Economic Growth in Fashion 11

$\begin{array}{ll}\text { Narratives of Fashion in Developing Economies } & 13\end{array}$

African Fashion: A Review of an Emerging Scholarly Field 16

$\begin{array}{ll}\text { Interview Method } & 22\end{array}$

2 / Case Study 1: Six Fashion Entrepreneurs in Ghana 26

$\begin{array}{ll}\text { Supply Chains and Fashion Networks } & 30\end{array}$

Branding, Representation and Aesthetic Considerations 37

3 / Case Study 2: Six Fashion Entrepreneurs in Nigeria 45

Garment and Accessory Production and Distribution 49

Developing Aesthetics in the Context of Material, Gender and Culture $\quad 54$

$\begin{array}{lr}\text { Conclusion } & 60\end{array}$

$\begin{array}{ll}\text { Acknowledgements } & 63\end{array}$

$\begin{array}{ll}\text { Appendix } & 62\end{array}$

A: Interview Outline $\quad 64$

$\begin{array}{ll}\text { Works Cited } & 65\end{array}$ 


\section{African Fashion Terminology}

Adire: The word adire in Yoruba means to "tie and dye"; to this are added words describing the various techniques of "tie and dye," such as adire oniko (raffia tied) or adire alabere (raffia stitched) (Spring 85).

Adinkra Cloth: An ancient Asante tradition of stamping cloth with Adinkra symbols using carved gourds (Spring 10).

Adinkra Symbols: Adinkra is an Akan word which describes the process of 'saying farewell to the dead' and it was in this context that adinkra symbols were first used. Each adinkra symbols is named and has a rich variety of nuanced meaning (Spring 10). Ankara Print: Also known as "African Prints" or "Dutch wax print," Ankara is a brightly coloured cotton fabric usually bought by the yard. Although they are associated with African culture they are derived from an Indonesian batik process of wax resist and massproduced largely in Holland by a company called Vlisco. Vlisco owns Ghanaian-based companies Woodin and Ghanaian Textile Print (GTP). There are many imitation wax prints on the market made largely in China called "fancy prints".

Aso Oke: Aso oke or "high status cloth," are woven and worn by the Yoruba in everchanging varieties of pattern, colour and material (Spring 132).

Batakari: A war shirt of the Asante people of Ghana protects its owner through a combination of magical signs and symbols drawn onto the surface of the cloth and protective charms encased in leather pouches attached to the front of the garment. The batakari, while maintaining its protective function, was also worn on ceremonial occasions - the batakari kese or "great war shirt" is still worn by paramount chiefs of Asante (Spring 175).

Bend Down Boutique: Markets that sell second-hand clothing where customers have to stoop down to find and pick items of interest.

Raffia: Long, narrow pieces of pale yellow dried leaf, especially from a type of palm tree, used as string or for making hats, containers, etc. (Cambridge Dictionary) 


\section{List of Participating Designers, A-Z}

\section{GHANA}

Afriyie-Kumi, Akosua

Dzidzienyo, Klekleli

Iddriss, Hassan Alfaziz

Kendona, Madonna

Manfreda, Stefania

Osei, Nana K Osei and Nana Boateng
AAKS (handcrafted bags brand, Kumasi)

Ameyo Clothing (clothing brand, Accra)

Hazza Underrated (Accra and Kumasi)

Raffia Clothing (Accra)

Elle Lokko (clothing brand and boutique, Accra)

Bohten (sunglass brand, Accra and Toronto)

\section{NIGERIA}

Egele, Uchechi

Ike, Joseph O. and Akindeinde, Ola

Ogisi, Oritsegbubemi (Bubu)

Oke-Lawal, Adebayo

Otitoju, Kunmi

Owolabi, Tunde
Marté Egele (Accessories brand, Lagos)

JZO (menswear, Kaduna, North Western Nigeria)

IAMISIGO (fashion brand, Lagos)

Orange Culture (androgynous menswear brand)

Minku (accessories brand, Lagos and Barcelona)

Ethnik (footwear brand, Lagos) 


\section{Introduction}

In 2016, Ghana's capital city of Accra, located along the Atlantic coast, was touted as “Africa's Capital of Cool" by the New York Times (July 2016), highlighting the growing number of boutiques, hotels and world-class restaurants. Just a couple of months earlier, on April 30, 2016, the Brighton Museum \& Art Gallery had opened the first major UK exhibit dedicated to African Fashion. The book Fashion Cities Africa, edited by Eritrean-born journalist Hannah Azieb Pool, was released the same month, and shares insights into the aesthetics and designs emerging from Nairobi (Kenya), Casablanca (Morocco), Lagos (Nigeria) and Johannesburg (South Africa). Since the start of the millennium, fashion journalists (Suzy Menkes and André Leon Talley) have been discussing the prevalence of high-end African fashion designers such as Duro Olowu, Lisa Folawiyo, and Folake Folarin Coker.

Meanwhile, stereotypes of "Africanness" including Ankara prints and tribal themes remain a source of inspiration for Western designers. As Victoria Rovine observes, "Africa seems to be the muse du jour for a wide array of designers, including Jean Paul Gaultier, Donna Karan, Kenzo and Dolce and Gabbana" (5). Luxury fashion has participated in creating an image of Africa that persists in the subconscious of the West. The online Nataal media (co-founded by Helen Jennings) features artists, designers and musicians from across the African continent, while Helen Jenkins's New African Fashion details a long history of African influence in haute couture as presented in the work of designers from Junya Watanabe to Thierry Mugler. What is less examined in the literature on African-made fashion is the experience of young and emerging fashion entrepreneurs growing their businesses in developing economies while competing in the international fashion market, which are the focus of this essay.

My Major Research Project (MRP) explores the experiences of such fashion businesses in two countries in West Africa: Ghana and Nigeria. These countries represent two unique comparative case studies that allow for an exploration of the emergence of African-made fashion through the lens of twelve Ghanaian and Nigerian entrepreneurs who are growing fashion businesses. This juxtaposition is prompted by the two countries' geographic proximity, though each country is highly distinct. For example, historically, 
Nigeria and Ghana did not share a common language; they have distinct Indigenous groups, and Nigeria's population is much larger than that of Ghana and its urban centres are vastly different in size. Nigeria's port city of Lagos is a megacity of about 20 million. At roughly 2 million inhabitants, Ghana's capital, Accra, is much smaller. Ghana and Nigeria are often compared, however, because of their shared heritage: both were British colonies and became independent within 3 years of each other (1957 and 1960 respectively). Following independence, both shared migration and trade. This study explores the differences and similarities within the fashion markets they participate in, on a local and global basis and any shared socio-economic and infrastructural barriers. More specifically, I consider some of the barriers these designers face, both on a local level with regards to infrastructure and within the context of broader economic issues across the continent.

The methodology utilized in this research includes a series of semi-structured interviews with fashion entrepreneurs from both Ghana and Nigeria. These twelve fashion entrepreneurs include fashion designers and the owner of a fashion boutique based in Accra. Each participant is from Ghana or Nigeria and currently resides in their respective country with the exception of one participant who lives between Barcelona and Lagos. It is through the generous participation of these twelve individuals, making their own stories and experiences available, that this research is able to shed light into some possible trends in the contemporary fashion industry in West Africa.

Ultimately, this research discusses the burgeoning fashion talent in West Africa as current and future competitors in the global fashion sphere, while underscoring unique opportunities and obstacles (such as cultural and socio-economic conditions in Ghana and Nigeria), and illuminating how African fashion designers navigate them. This research adds to a growing body of work on contemporary West African fashion while uncovering some of the narratives that encompass fashion from the continent including foreign investment and fashion development initiatives. Furthermore, it explores issues of infrastructure, financial support, and market competition caused, in part, by cast-off clothing donations from the West (Frazer 1765), and the scarcity of trained tailors and dressmakers that meet international standards. As we shall see in this essay, shortage of dependable infrastructure, which includes problems with routine power outages and 
inconsistent Internet access, are still a daily reality for those working in cities like Accra and Lagos (Jennings 17). Building a business with some of these infrastructural shortcomings presents unique challenges for African brands that are positioned to compete with Western ones. This research looks at the ways in which Ghanaian and Nigerian brands are able to overcome these barriers and examines which factors pose the greatest risks to their business.

At the outset of this research project, I visited Ghana and Nigeria for a five-week period; I provided consultation for an emerging fashion brand, Raffia Clothing, and conducted on-site research into scholarly and journalistic sources on the topic of contemporary West African fashion. This was a journey that left powerful memories and images, some of which I share in this MRP. I begin by reviewing the relevant literature that underpins this study, as well as the method before moving to my case studies to share the voices of the participants. I am grateful to each and every one of them. 


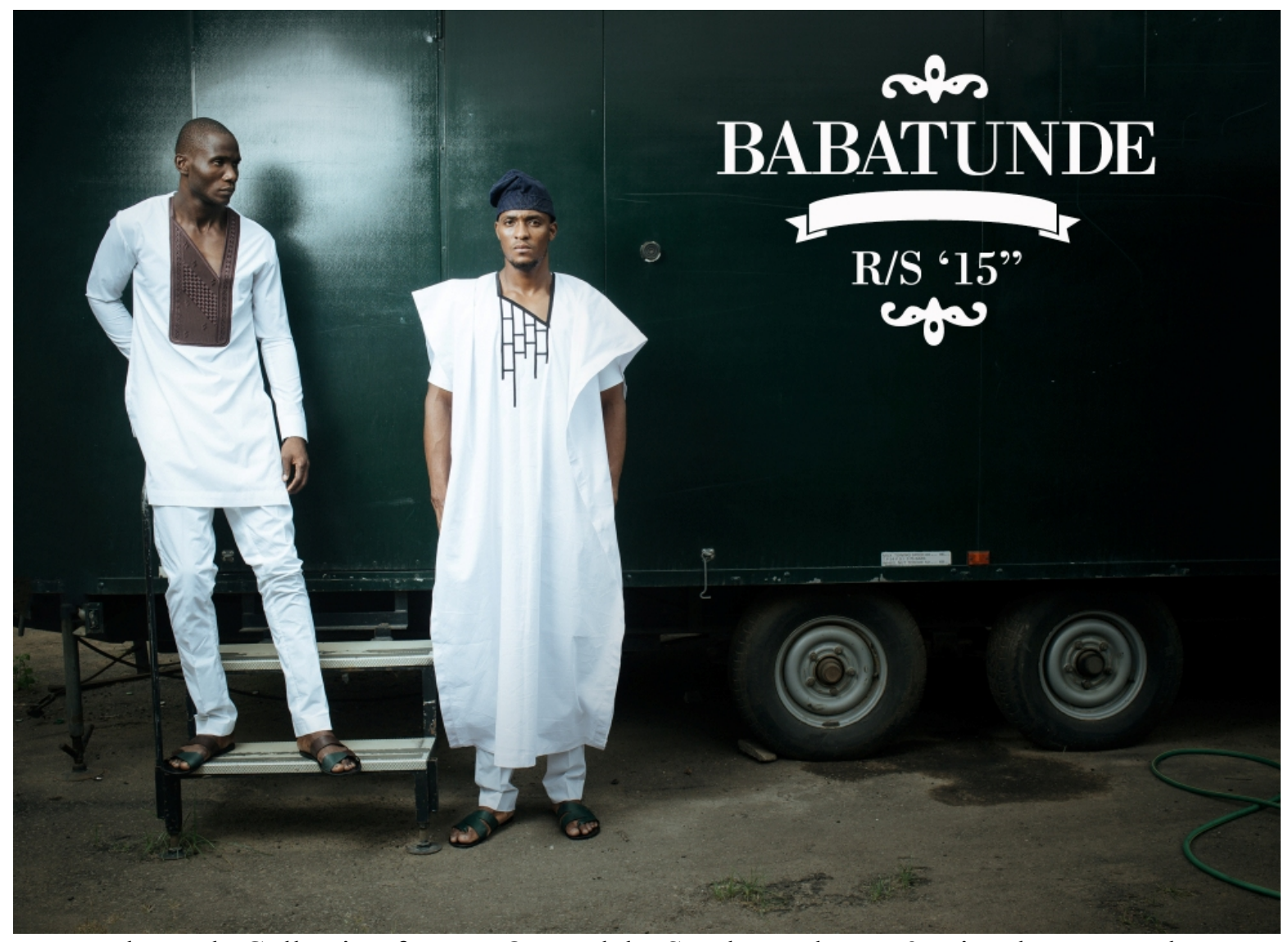

Babatunde Collection from JZO. Models: Sunday Balogun \& Kingsley Eze and Photography: Aham Ibeleme. Photo courtesy of JZO. 


\section{Chapter 1:}

\section{Toward a Method for Studying Africa's Economic Growth in Fashion}

The growing interest surrounding African-made fashion has emerged alongside an increasingly positive social and economic outlook for a continent that has historically been associated with poverty and conflict. The term "Africa Rising" was more than a headline trend that gained traction in media such as the Economist (3 December 2011) and the New York Times (3 December 2012); it was also a term coined to delineate the perceived optimistic futures for many African countries, which were increasingly exhibiting signs of stability and growth (Onuoha 278). Africa Rising was also the title

of the Spring Meeting conference in 2014 initiated by the International Monetary Fund (IMF) and World Bank Group (WBG) that was designed to organize around the growing economies on the continent (Nega \& Schneider 283). Meanwhile, fashion headlines around the world read "Made in Africa: Is Manufacturing Taking off on the Continent?" (BBC May 2014) and "Africa Emerging as Next Frontier" (Women's Wear Daily July 2014). This optimistic outlook was founded in good faith, but much of the reporting has chosen to focus on a few key players while overlooking the obstacles that new entrepreneurs were facing. While many African countries experienced a 5\% increase in GDP between 2011-2014 (African Economic Outlook 24), some economists have recently become less optimistic about what these figures have meant for societies. Godwin Onuoha outlines that the shift from "afro-pessimism" to "afro-euphoria" has overlooked the need for better policy with regards to equitable distribution of wealth, governance and social welfare programs (27). Until then, his concern remains that resource-related wealth will linger in the hands of the rich, providing little improvement for underserved populations.

The African Economic Outlook 2016 report echoed Onuoha's call for better policy across African countries to promote rapid and inclusive growth, noting the persistence of high rates of poverty across the continent (4). In October 2016 the IMF identified that despite a period of growth between 2011-2014, a trend has emerged in recent years that is being dubbed "the tale of two Africas," meaning that countries that are non-renewable 
resource dependent in particular have felt the decline the most (5). Reports from the AEO stipulate that the slowdown in growth in 2015 was due to weakening global demand and a drop in international commodity prices, having a negative impact on Africa's resourcerich countries but that the continent on a whole experienced the second fastest growing economy in the world (24). While studies have shown an increase in the service sector, a shift from agricultural labour and a growth in overall consumption, the middle class has been notoriously difficult to define and track across countries in Africa (Resnick 583). Despite these changing perceptions of prosperity, new fashion brands continue to emerge across the continent. The pressing question is, how do they ensure strong incremental growth to survive in a competitive global market?

The implication for the lack of structural transformation has particular resonance for emerging creative industries in African countries. In 2010, the United Nations (UN) released "The Creative Economy: A Feasible Development Option" - a follow up to a 2008 report that concluded that creative industries were among the most dynamic sectors of the world economy and offered substantial growth opportunities for developing countries (17). The 2010 report cautions that countries that do not nurture their creative talent risk the loss of cultural heritage, and highlights Ghana and Nigeria specifically for their commitment to supporting creative industries (44). Nigeria has long been recognized for its output of musical talent, from Fela Kuti to Sade to Wizkid, as well as its booming film industry. Beyond individual success stories, there are substantial sectors emerging. For example, according to the 2014 United States International Trade Commission (USITC), the Nigerian film industry (also known as Nollywood) employs over one million people, generating $\$ 600$ million annually (USITC) and has done so without help of government support or international funding schemes (Akudinobi 133).

The above context presents some of the intricacies of economic policy across developing countries within Africa that experience frequent economic and/or political changes and are susceptible to international fever of perceived growth. In response to the evidence of Ghana and Nigeria's burgeoning talent, a few high-level opportunities have been presented to support those wanting to establish themselves as entrepreneurs or those wanting to move beyond the start-up phase of their fashion business. The Tony Elumelu Entrepreneurship Programme (TEEP) is a pan-African initiative that provides monetary 
support for a multitude of industries from textiles to agriculture. The Nigerian Exports and Promotion Council (NECP) as well as the Bank of Industry (BOI) offer programs that include either financial or capacity building support for those in the fashion industry. The African Growth and Opportunities Act (AGOA), established in 2000, allows duty free access to US markets for some qualifying Sub Saharan countries. These mechanisms are not necessarily solutions to establishing a thriving creative economy; however, they have been cited by some designers (discussed below) as having aided their development as fashion entrepreneurs.

\section{Narratives of Fashion in Developing Economies}

The world of fashion offers multiple streams in which clothing is produced and distributed beyond the major fashion brands that fill mainstream retail centres globally. This is particularly true in regions with a developing economy where influence might be felt from industrialized regions. Christian Rogerson, professor of Geography at Witwatersrand, South Africa discusses the growing literature that "confirms the importance of understanding the uneven nature of power relationships in the global clothing economy" (217). Rogerson argues that large retailers and brands control global networks due to their ability to shape consumer demand in a highly competitive space. While some brands undoubtedly have greater global influence than others, there are entrepreneurs, counter-movements, and development initiatives that play an important part in how fashion is consumed. This adds to the complexities and narratives surrounding the overly homogenous term "African fashion."

The first African fashion narrative involves the goodwill enterprises that help support underserved populations. Fashion is not often regarded as the primary avenue for developmental growth, though it has not been entirely overlooked as an opportunity for incremental change on a non-industrial level. In 2009, Simone Cipriani founded the Ethical Fashion Initiative (EFI), a program of the International Trade Centre, which connects designers in and outside of Africa with highly skilled artisans that are in need of meaningful employment touting the motto "Not Charity, Just Work." Additionally, there are many fair trade companies and non-profit organizations that employ people, 
predominantly women, in developing African countries (and beyond) in order to provide subsistence income and preserve craft. These include Global Mamas based in Ghana, Ten Thousand Villages, which operates in 29 countries worldwide, and Krochet Kids International working in Uganda and Peru. According to Natalie Domeisen, fashion is a market-driven, sustainable development opportunity that responds to consumers who are educated, affluent and style-conscious and are looking for good quality garments developed through socially conscious means (ITC 13). In 2012, the late Franca Sozzani, former Editor-in-Chief of Vogue Italia, became the global goodwill ambassador of Global Fashion for Development (GF4D). Founded in 2011, GF4D is a UN initiative that helps support economic and social development activities in fashion and textiles with a particular focus on empowering women.

The second fashion narrative that is prevalent in Africa's growing economies is the movement of entrepreneurs from more developed countries who are building forprofit enterprises in developing ones. Some of these companies include Edun Clothing, producing womenswear in Kenya and Madagascar; Osei Duro, producing mens and womenswear in Ghana; and Ten \& Co., producing footwear in Morocco. According to Abor and Quartey, domestic small and medium size enterprises (SMEs) are positioned to create employment and perpetuate the development of skilled labour (218) while foreign direct investment "has the potential to contribute to the upgrading of local suppliers through technical assistance, training and the transfer of knowledge" (Smallbone 87). Furthermore, since many fashion labels, such as Ghana-based Yevu Clothing, use local artisanal labour skills, it is feasible that they can contribute to the preservation of craftsmanship. Some of these companies could be recognized as providing foreign investment. Others could be classified as domestic SMEs depending on their business structure and where they are headquartered, however, the hybrid nature and management of these companies complicates the narrative of what makes an authentically African company.

The above narrative represents a trend towards socially responsible fashion, having emerged in direct response to the problematic ways in which a growing number of large-scale fashion brands operate. Since the mid 1990s, companies that helped perpetuate the fast fashion model have faced greater scrutiny for their use of sweatshop labour, poor 
working conditions, environmental damage and for favouring obsolescence (Koslowski et al 18). This model was achievable because of the willingness of companies to outsource production to areas of low wage labour for the competitive success of their brands. While this brought jobs to developing regions it also led to the subcontracting of value added activities (Taplin 73) making it more difficult for companies to be held accountable. While these companies are more widely known to produce in areas of China, Vietnam and Bangladesh; factory collapses, overworked and underpaid labour forces, as well as environmental degradation were among the concerns that catalyzed the urgency for ethical fashion. Outward-looking entrepreneurs sought out socially-minded businesses (Blockshop Textiles, Hiptipico, Bolga Baskets) in countries where hand-made, artisanal objects or textile techniques are produced: Indian block printing, Guatemalan embroidery and Northern Ghanaian basket weaving.

The third narrative is the influx of clothing that has been discarded from the West and sold in markets throughout countries in Africa including Ghana, South Africa and Ethiopia. These markets are termed "bend down boutiques" in Ghana because of the need to physically bend down and sift through piles of clothing to find the desired garment. Pre-owned, donated American and European clothing is sold either in bulk or by item at a price point that is highly reduced from its original value. These acquired garments supply populations with a low-cost solution for clothing needs, but has been flagged by African policy makers as harmful to their domestic garment industries (Fraser 4), though this financial burden is difficult to track (Brooks \& Simon 20). Some designers have incorporated these market garments into their design strategy by deconstructing or altering market clothing, as we shall see below.

Tailor-made clothing, the fourth narrative, is one of the many informal economic sectors in Ghana. Women and men regularly visit their tailors to have items made for the office, events, or daily life, allowing customers to have garments made to order. This may include garments like the Ghanaian Kaba, a three-piece ensemble consisting of a kaba blouse, a wrapped skirt and a third cloth that can be used as a headscarf or overskirt worn widely throughout the Ashanti region and derived of a blend of European and indigenous dress (Gott 11). Tailors and seamstresses are trained through apprenticeships and can be 
found widely throughout Ghana and Nigeria offering to make copies of existing designs or providing their own variations on popular garments (Rovine 23).

The fifth narrative includes designers who originate from an African country and have established commercially successful fashion brands abroad, such as Duro Oluwo in London, U.K. These designers tend to receive a large amount of international press while still maintaining an association with the African context. In the sixth narrative to be discussed in this paper are the many African designers who may not be affiliated to any particular good-will organization but, by practice, are employing local tailors and artisans while redefining local fashion and nourishing their local economy. Their non-affiliated voices are often absent from some of these discussions unless they have reached a certain notoriety in their career. Rovine states that "while Africa's profile in international fashion circles has been heightened by its appearance as a source of inspiration for Western designers, the many African designers who are themselves engaged in innovative transformations of African style receive little attention in the international fashion press" (136).

In Birth of the Cool: Style Narratives of the African Diaspora, Carol Tulloch discusses the significance of objects in meaning-making. Specifically, she references the afro-comb as a way to "illustrate how an object can provide a contemporary narrative on a previous pivotal moment in African diaspora political cultural history" (153). Further, Tulloch references Hopper-Greenhill's claim that "objects are the inscribed signs of cultural memory" (156). If we look at fashion collections as objects, each article of clothing contributes to an output of cultural memory-making. Because there are multiple ways in which fashion is being produced in Nigeria and Ghana, meaning is not static nor of one origin. These multiple narratives of fashion generation are part of a paradoxical discussion of meaning, ownership, appropriation, support, entrepreneurship, development and opportunity - discussions that the world of fashion could see more of in the coming years as either formerly sluggish or unpredictable economies experience longer term stability, or formerly high-potential economies suffer from negative headwinds.

African Fashion: A Review of an Emerging Scholarly Field 
Scholarship on African fashion and contemporary brands is a small but growing area of study, which reveals the problematic in ascribing practices as inherently "African" or "Western" (Rovine 134). For example, Karen Fiss asserts the concept that fashion has long been associated with "advanced societies" and "non-Western dress historically has been considered costume and not fashion" (8). Much of the academic literature is primarily concerned with textiles, craft and adornment and practices of dress during the colonial era, such as "Fashioning the Colonial Subject" by John Comaroff and "Weaving a Biblical Text: Ewe Cloth and Christianity" by Malika Kramer. Both works provide insights into the complex histories of textile practices, as well as a critical study of the evolution of dress. Victoria Rovine and Leslie W. Rabine have looked at fashion from a contemporary vantage point, approaching sartorial style in terms of "fashion from the continent" rather than "African fashion," the latter conveying an image of homogeneity.

In this, Hannah Azieb Pool offers a helpful perspective for my study, as she writes: "there is no such thing as African fashion any more than there is 'European' or 'North American' fashion" (Pool 14). In other words, each city harbours its own history, priorities and influences, which are reflected in the work of designers. Thus, in concert with Pool's perspective, I direct my focus on designers that are based in Ghana and Nigeria that are working within the economic, structural, and cultural systems of these countries. Each brand contributes to an output of meaning that redefines the place and culture from which they emerge.

One of the realities of the fashion industry in Ghana and Nigeria is that its high price point makes this fashion unaffordable for many in the country in which it is made. Rovine states, "only consumers of substantial means can afford to purchase the clothing that is shown on runways, sold in boutiques, and promoted via glossy magazines" (108). While some of the companies I encountered in my research could appeal to a broad market, they are in reality only accessible to a small portion of the local population while inadvertently representing an aesthetic that positions them as important signifiers and identifiers of place. As Schroeder et al. state in Brand Theory, "in the practice of brand management, companies are constantly engaged with issues of social and cultural identity" (116). Further, many of the designers incorporate elements that are 
historically associated with West African aesthetics such as the batakari, a Northern Ghanaian smock, or a basket-weaving technique re-adopted to make clutch purses instead of market baskets. This work redefines and rebrands the original uses for these techniques while connecting their work to a local context.

Jennings outlines regionally specific textile practices such as the West African boubou and agbada (embroidered gowns with Islamic influence) and the shweshwe (printed indigo cloth) worn by Sotho people in Southern Africa (3). Her expertise shows that many young African designers study abroad and return to their countries to create hybridized contemporary garments. Her book New African Fashion (2011) gives an overview of the high-end fashion landscape across Africa. She was also editor of now defunct Arise (2009-2013), an online African culture and lifestyle magazine. In addition, there are fashion blogs shedding light on the use of African print/Ankara print among the African diaspora, such as OkayAfrica.com founded by Ginny Suss and run by Abiola Oke, and Africanprintsinfashion.com written by MsK of New York. Throughout my research in Ghana and Nigeria I explored local media context, reviewed TV programs (including An African City set in Accra), fashion events (Lagos Fashion and Design Week and Ghana Fashion Week), as well as locally circulated magazines and blogs (including Bellanaija, Africa 2.0 Magazine). While English is the official language of both countries, and most media broadcast English in Accra and Lagos, a multitude of languages are spoken in each, including Yoruba in Nigeria and Twi in Ghana. These factors add to the barriers that hinder my complete understanding of local experience. The social media platform Instagram played a pivotal role in my research, as it provides links and suggestions to brands that I would otherwise not be familiar with or be able to find through English-language search engines. The suggestion platform on Instagram assisted in rapidly broadening my knowledge of existing and emerging brands that do not otherwise get wide coverage in Western media streams.

In "Colonialism's Clothing - Africa, France and the Deployment of Fashion," Victoria Rovine uses a postcolonial model to explore how French West Africa was depicted in French clothing in the early $20^{\text {th }}$ century, when African fashion was pejoratively labelled "traditional." This cultural bias is sometimes perpetuated in fashion journalism today as exoticisation. Rovine argues that boundaries of cultural identity 
should not be viewed as separate from one another: “ 'African' or 'Western' styles are points on a continuum rather than discreet categories" (5). These distinctions are often lost in the marketplace; multiple North American and European style blogs feature housewares that incorporate Ankara print (largely produced in Holland and China), often allowing customers to introduce "ethnic" elements into their home without having to commit to deeper engagements and histories of the products. As Jennings notes, "European designers choose certain colours or materials without necessarily understanding their value" (14).

In "Dilemmas in African Diaspora Fashion," Lewis Van Dyk articulates concerns about making short-term trends of other people's cultural history; the "borrowing and adaptation" of cultural aesthetics can lead to "sartorial conventions" (Rovine 47). While not specifically focusing on "African print," Gott and Loughran's book Contemporary African Fashion identifies where colonization has left its mark on current fashion trends while being interlaced with localized techniques, stating that "in today's globalized world style inspirations travel in all directions" (5). The authors highlight where this has been successful and when it has proven problematic due to certain forms of dress holding deeply imbedded meaning or association to specific traditions. Leslie Rabine investigates the informal transmission of African fashion in The Global Circulation of African Fashion: Dress, Body, Culture. Rabine provides insight into businesses operating outside of the traditional networks of business in regions of Senegal, Kenya and Los Angeles and how artisans reinterpret and adapt traditional designs in order to compete with their peers and make a living in the precarious world of design. She explains that through adaptation, artisans are helping dispel the colonial idea of tradition as static. Although this paper does not investigate informal fashion networks, her discussion on tradition and adaptation is helpful in the context of postcolonial theory.

African-inspired design has been used in Western fashion for a number of years from Thierry Mugler's spring/summer 1987 collection to Junya Watanabe's spring/summer 2009 collection (Jennings 13). In the last 10 to 15 years, however, there has been a growth in what Leora Farber terms "hybridised identity options" (129) in her article "Africanising Hybridity? Toward an Afropolitan Aesthetic in Contemporary South Africa." She examines three Johannesburg-based designers, Sun Goddess, Stoned Cherrie, 
and Strangelove, who have what she references as an "Afropolitan" aesthetic "in which both African and cosmopolitan aesthetics are reworked and integrated" (Farber 29). Postcolonial theories like Farber's privilege an understanding of hybridized identities, providing insight into the designers' histories and identities. However, this risks perpetuating Western designers as progressive, contemporary and fashion forward while African designers could be seen as romanticising the past. This dichotomy could locate Westerners as leaders in fashion (despite a practice of recycling their past in post-modern fashion) while relegating African designers to endlessly renegotiate their pre-colonial histories.

Furthering the discussion of hybridity, Hansen and Madison's edited collection African Dress: Fashion, Agency, Performance (2013) features chapters from a group of scholars who incorporate ideas of performance and identity in discussing clothing across disparate regions within Africa. The editors describe African aesthetics as "visibly global and resolutely local at the same time" (9). The authors assert that clothing can signify power, status, religion, and gender as well as awareness of and "plugging in" to Western trends. In this work, dressing well helps individuals in difficult economic times reclaim power. The authors bring to light the importance and weight that clothing bore historically and contemporarily in disparate social groups. Among low-income earners in Niger, "men and women share intense preoccupation with clothes" (143). The Senegalese norm of "looking good" is "one way of coping with economic adversity," and the author notes that "fashion thrives in Senegal despite decades of economic decline" (63). In colonial era Togo, showcasing one's wealth was important during social functions and this was typically done using the expensive Dutch wax fabric. Also known as African Print or Ankara Print, Dutch wax fabric is also a central textile print in current and colonial era African fashion around which much of the scholarship is based.

A key piece in understanding aspects of West African textiles and of the broad term "African print" is the example of the Dutch company Vlisco founded in 1846. Vlisco uses a wax cloth method in its textiles that is historically an Indian and Indonesian practice. While these products are designed and manufactured in Holland, they are sold predominantly to African markets. In their article "The Commodification of Ethnicity: Vlisco Fabrics and Wax Cloth Fashion in Ghana," Christine Delhaye and Rhoda Woets 
note that "The multi-layered history of wax cloth is embedded in a long and ongoing history of global trade and cultural (re)appropriation" (94). Although the brand has been copied and manufactured at cheaper rates in China, "fancy prints," as they are called, still sell to a large market and remain a strong identifier of African aesthetic. Ghana Textile Printing (GTP) and Woodin are Ghana-based textile producers owned by the Vlisco Group.

In his 2010 article "The European 'African Print' and the Direction of Authentic African Print Design Efforts in Nigeria," Nigerian scholar Tunde Akinwumi takes a critical postcolonial approach to document that Vlisco does not feature indigenous African motifs. Instead, Indian, Javanese, Indonesian, European and Chinese inspired designs have been and are currently used, thus effectively misrepresenting African heritage. In his 2008 article “The 'African Print' Hoax: Machine Produced Textiles Jeopardize African Print Authenticity," Akinwumi documents that the prints are actually "developed from batiq" a technique that is indigenously Indian (181). Historically, Christian missionaries introduced wax prints to West Africa before the Dutch company began producing largely for West African markets (182).

While my research takes inspiration from scholarship on hybridized identities and Ankara print, which represent an already well-established scholarly subfield, it does not focus on these topics alone. The research focuses on an underexplored domain of African fashion, namely, the access and barriers that young West African brands face, both locally and internationally and the ways these issues manifest. Pool and Jennings detail these problems, noting that "weak infrastructure includes poor transportation and an inconsistent power supply... a lack of trained tailors and seamstresses and no big manufacturing factories" (91). Likewise, Franklin Obeng-Odoom's "An Urban Twist to Politics in Ghana" is informative, noting that Africa has one of the fastest rates of urbanization in the world, though with largely disproportionate income earnings. ObengOdoon suggests that Ghana in particular has a reputation as a strong and stable political body, represented in the recent work in beautifying the city of Accra, building business centres, malls and supporting the arts. To what degree financial backing is given to those in the arts and to fashion is not readily available in current scholarship and while poverty rates are decreasing outside of the capital, Obeng-Odoon notes that they have risen in the 
city Accra.

In "Culture and Nigerian Identity in Print Media," Onyinyechi Nancy Nwaolikpe discusses the role print media should take in furthering and preserving Nigerian cultural identity(ies). The author underscores that because Nigerians use the Internet and television as a main source of information consumption, there is a large influence from the US, perpetuating an American ideal over a more local way of life. She also suggests that not enough effort is being placed on preserving local culture and states: "only a few newspapers are written in indigenous languages" (7) which, combined with greater Western influences on culture, is placing local cultures at risk of being diluted. At the same time, social media helps spread awareness of up and coming brands and artists across the continent and beyond. In "The Intimacies of Four Continents," Lisa Lowe states that "liberal forms of political economy, culture, government, and history propose a narrative of freedom overcoming enslavement that at once denies colonial slavery, erases the seizure of land from native peoples, displaces migrations and connections across continents, and internalizes these processes in a national struggle of history and consciousness" (3). In a free market economy, countries that have been historically held back due to colonialism, such as Ghana and Nigeria, are in a paradox of contending with their relatively recent freedoms while operating within systems established in the postcolonial marketplace that provides little acknowledgement and sweeps recent histories under the rug. Some of these cultural and theoretical concerns would become evident in the interviews I conducted in Ghana and Nigeria.

\section{Interview Method}

Given the problematic outlined above, talking directly with the fashion designers and recording their voices and words was essential to this study. This research was conducted using snowball sampling to locate participants. Snowball techniques build a sample "created through a series of referrals that are made within a circle of people who know one another" (Sven Berg, Snowball Sampling - I, 2006). The reason for using this approach is as follows: First, for the purpose of my research on emerging designers, it 
was imperative that I gather information from those who have attempted to or are looking towards working within international markets and who are accessible via email. Second, obtaining the trust and interest from a designer to participate in the research proved to be less complicated if we shared a mutual acquaintance. Third, while I have foundational knowledge on the brands that are emerging in Ghana and Nigeria, I welcomed local knowledge on the fashion landscape in both countries and valued information shared from those who reside on the continent.

To reach participants there were instances where a mutual acquaintance contacted designers they knew, providing introductory information about my research and my desire to interview them. Their email included the consent form and a brief description of my intended study along with my email address for the designer to contact me. It was then up to the designers' discretion to contact me if they agreed to participate. There were also designers whom I contacted directly under the condition that their email addresses were already public.

The majority of the interviews (eight) were conducted in-person in Ghana and Nigeria in August and September 2016. Four interviews were conducted via telephone or Skype following my return to Toronto between September 2016 and February 2017. Interviews were recorded, transcribed and returned to the participant for review along with their written consent. I interviewed a total of twelve fashion entrepreneurs (six from Ghana and six from Nigeria). All participants were over 18 years of age, with no limitation placed on the size of the company. It was the goal of this research to interview designers who are looking towards international markets or have done so already. Designers were asked about the inception of their business, their aesthetic choices and their target market, as well as the progress and setbacks they have experienced since starting their company (see questions in Appendix A). Lastly, I posed questions on the company's trajectory, how they were planning to achieve those goals, and how they identified any risk factors or barriers.

As we shall see in the two case studies of Ghanaian and Nigerian fashion presented in chapters 2 and 3 below, there is a remarkable diversity of fashion brands with the research dispelling some the stereotypes noted above. The twelve participants include Akosua Afriyie-Kumi, founder of the brand AAKS based in Kumasi, Ghana. Afriyie- 
kumi produces handcrafted bags, woven by expert artisans in Northern Ghana, lined and finished by Afriyie-Kumi and sold internationally. Tunde Owolabi, based in Lagos, Nigeria is a photographer and graphic designer who launched a business in footwear in 2015. Employing local cobblers, Owolabi produces shoes made from Nigerian woven fabric called aso oke, which he designs himself. Stefania Manfreda is the owner of the clothing boutique Elle Lokko located in Accra, Ghana. Manfreda promotes African-made merchandise sourced from across the continent including her own line of t-shirts. Collectively the participants shine a spotlight onto the West African fashion industry that is not often covered by Western media.

The 12 participants provided written consent to reveal their names, include photographs and provide a visual tapestry for readers of this MRP to engage with the designs; this will also enable readers of this MRP to locate the designers online for further study of the brands. The purpose of this research is to present key trends, give voice to the experiences of emerging Nigerian and Ghanaian fashion entrepreneurs, ultimately to illuminate an underexposed area of research in fashion theory. Chapters 2 and 3 will present the findings from participants in Ghana and Nigeria, respectively. In order to better understand the inspirations and interests of each designer within the fashion space branding and aesthetics are key themes to be explored. Each entrepreneur discussed the type of products they generate, the influence of place on their work and how they contribute to a contemporary understanding of African-made fashion. Individuals were asked about their marketing strategies, product distribution and international stockists. In order to tackle stereotypes surrounding the use of "African print" each entrepreneur was also asked to discuss the fabrics they use.

Those that participated in the research discussed their production process that included access to skilled labour and a consistent workforce as well as their key infrastructural concerns. Designers shared the financial challenges of launching and running a business in their country, including cash flow and access to financial support. Lastly, designers expressed what they feel are the key areas for improvement and the perceived advantages of supporting and growing their local fashion industry. And now it's time for the fashion designers to have their say as we turn to the Ghana case study. 


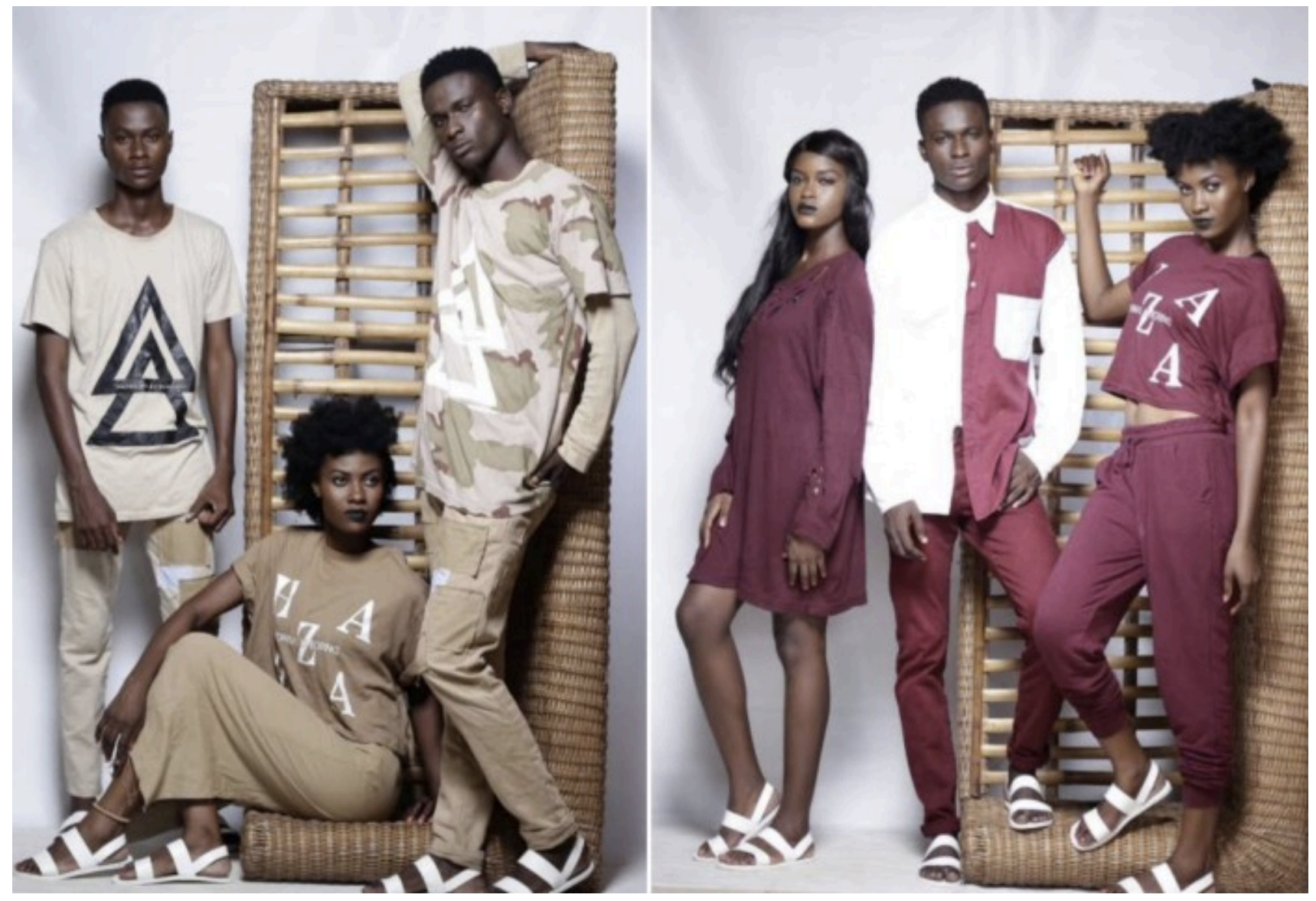

Redefined II Collection from Hazza Underrated as featured in Fashion Walk Africa. Photography: Quincy Koranteng/Hazza Underrated Models: Ekow Barnes, Prince Tona, Karen Abiba, Maureen Essah. Makeup: Hamid Vijay. 


\section{Chapter 2}

\section{Case Study 1: The changing landscape of contemporary fashion production in Ghana as seen through the lens of six entrepreneurs}

I met Stefania Manfreda in her fashion boutique, Elle Lokko, based in downtown Accra amidst a bustle of businesses and shops and restaurants, fronting Lokko Street. Here in this airy space that Time Out (January 3, 2017) described as "the epitome of urban cool," the owner and founder of Elle Lokko recalls a time when Ghanaians would only wear Ghanaian-made clothing. This was before the first mall was built near the Kotoka Airport and the influx of affordable second-hand clothing, which soon flooded the markets, as Manfreda explains the dramatic changes since the opening of the Accra mall in 2008:

So you'd see a lot of people there not for shopping but to take selfies and pictures. They had to ban people from taking pictures at some point because the stockists would complain because it was packed but no one was buying. So there's all this new stuff that was happening and people are just now coming to grips with it.

As other participants confirm, it is not just retail that changed or the number of designers that have emerged in the last five years, but the industry as a whole that includes a network of creative individuals to support the growing industry. "Now we have people who are stylists, make-up artists, photographers," as Creative Director of Ameyo Clothing, a Ghanaian women's wear brand, Klekleli Dzidzienyo concurs, noting that when she first started making collections in 2013, it was difficult to find a fashion photographer in Accra.

Other designers in Accra echo this emphasis on transition and growth of the fashion industry, while also noting some of the growing pains of launching a new business. The entrepreneurs, many of whom have embraced some western fashion marketing cues, face one common issue - cash flow, which is one of the greatest challenges in pushing their businesses forward - and a reality that entrepreneurs on any

continent may feel in the early years of their business. On the positive side, labour and material costs in Ghana are often lower than in developed economies and access to traditional handcrafted goods are a unique advantage to those beginning an artisanal 
enterprise. That said, fashion entrepreneurs in Ghana need to have existing capital or an investor willing to supply cash up front. In largely cash-based economies, like that of Ghana, start-up costs can prove to be an even greater challenge. Residents who own a car likely acquired one because of their ability to pay for it in cash. Domestic flights are bought in-person and paid for in cash. Fabrics and notions are paid for in cash. Rent is pre-paid, two years (and up to five years), in cash. Access to credit from a local bank might be available, but at costs that are unattractive to young entrepreneurs. Also headquartered in Accra, Madonna Kendona, Creative Director of Raffia Clothing, who launched her fashion business in 2013, states: "There are no readily available funds or access to credit here. You can get a loan but it's very likely that your interest rate is in the 30 s in terms of percentage and that could cripple a growing business and that's not something I've ever wanted to tap into."

Those that can acquire help from friends or family members are lucky, as many young designers call attention to the older generations who often do not see stability in the creative economy. Many of the entrepreneurs interviewed had studied what are considered to be traditionally more lucrative fields such as business or computer science before deciding to launch their own fashion brand. The sentiments regarding this generational divide are perhaps best summed up by Akosua Afriyie-Kumi, Creative Director of AAKS, and listed as 'One to Watch' by Forbes Woman Africa, who describes the expectations placed on children. Having studied fashion in the UK, she recognizes that not all parents are supportive of the idea, although hers were, as she explains:

Arts are not valued in Ghana. No parent wants his or her kid studying fashion or fine art. They feel you won't make money. Of course, I went to the UK and parents value that...[laughs], it's completely different. They want you to be a doctor or an engineer, I don't know, that sort of thing. My parents are like that... Parents do not want their kids to get into the creative arts. I kind of got away with it - I don't know why.

Nevertheless, young people are pursuing a creative enterprise and in Accra, in particular, there is no shortage of creative experiences, such as the Chale Wote Street Arts Festival (CWSAF) in Jamestown, Accra running for a weekend in August every year. Such events contribute to Ghana's reputation as a tourist destination (Ray 509). 
While some of the designers have retail shops abroad in cities like London or sell to major retailers such as Anthropologie, each of the participants emphasizes their objective to expand their business in the ensuing months and years. Some of the smaller brands have customers around the world, receiving orders from Paris, New York, and Johannesburg. Despite international orders, some designers are finding that many of their local customer base is used to a more tactile experience with items rather than buying items online, making pop-up shops an ideal way to gain visibility with new markets within the continent. "People in Africa do not buy online," says Afriyie-Kumi. "Barely do I have sales from Africa from my online store. They also don't have debit cards or credit cards. It's not something we use here, everything is cash [based]. You have to pay with cash so we are not used to shopping online or credit cards." Afriyie-Kumi noticed an increase in her visibility in Accra after holding a pop-up shop there, as she explains: "In Europe and developed worlds, everyone is used to buying online so it's easy. So that's the big difference here.” For some, the opportunity of living abroad has assisted in developing relationships or leveraging existing ones in order to expand the reach of their brands. However, even with established contacts some designers are feeling a lag in external buyers acquiring their goods. The hesitation behind foreign investment could stem from the potential risk associated with the perceived inefficiency of some of the factories and a greater need for international level standards when it comes to tailoring, mentioned previously.

Others have cited feedback about their use of bright colours as not appealing as much to a European, specifically Scandinavian, market where products tend to have a more muted colour palette. How a brand is marketing itself can also determine the attraction of external retailers who might be searching for something they can market as "ethnic" for their retailing needs. For some designers, this can be perceived as a marketing ploy rather than a long-term relationship that recognizes them as a competitive, viable fashion brand on par with that of the West. "There are very few people who manage to get placed and get retailers outside of the continent," as Kendona explains. "A lot of people are advertising themselves as an African brand and we want to differentiate ourselves from that because I think another issue is the fact that our brands tend to be exoticised 'oh it's an African brand!' and it's not taken at face value. [Do they ask 
themselves] is this a good garment regardless of where it's coming from?" Echoing Kendona, Manfreda also acknowledges how exoticisation can stifle an industry, reminding us also of Rovine's assertion that Africa has oft been seen not as a modern fashion hub like that of New York or Milan but as an occasional source of inspiration (“Colonialism's Clothing” 134).

Despite a shared interest in working with retailers off the continent, many of the brands like Bohten and Raffia and Elle Lokko recognize great opportunities in countries on the continent including South Africa, Kenya, and Nigeria where there is a large market for fashion aficionados and where they will be in good company with other fashion designers and other creative practitioners. African fashion has moved beyond colourful was prints, as Manfreda emphasizes: "It's just not that anymore. I mean people are really experimenting and pushing it. That's why I think, for me, it's important first that we deal with our local markets, as in the continent (not just Ghana), and create connecting points within this continent before addressing the Western world. Because we are in a tropical environment, first of all, so we won't follow the seasons. I don't do a collection change in winter, spring, autumn."

The entrepreneurs interviewed also describe a definitive sense that the Ghanaian fashion industry has a growing momentum. Despite the fact that fashion from Africa is still often found in the back pages of Vogue Italia or an online blog that has found a designer to promote, designers express confidence that the African continent will experience considerably greater attention in the coming years. Nana K Osei, Co-Owner of the sunglass brand Bohten, states: “[Fashion] definitely changed. There's a lot more awareness about what can be done. I think companies are pushing the boundaries in terms of this idea of what African is. There is slowly becoming a separation between culture and fashion which is what people look at in African fashion." But for Manfreda there are leaps to be made before Accra is considered a fashion capital:

I think there's a lot that needs to be done. The fashion industry that has been in Milan has been there for a long, long, time as an industry. We don't know what an industry is yet. We are still producing the one-off collections and really struggling if we're going to keep up with the seasons for Western consumption. So, we need 
to have the whole set-up in place first before we can then say "ok this is the new capital in Africa for fashion."

Manfreda's vision for Accra is pointed: "Not necessarily for African fashion," she specifies, "but a fashion capital."
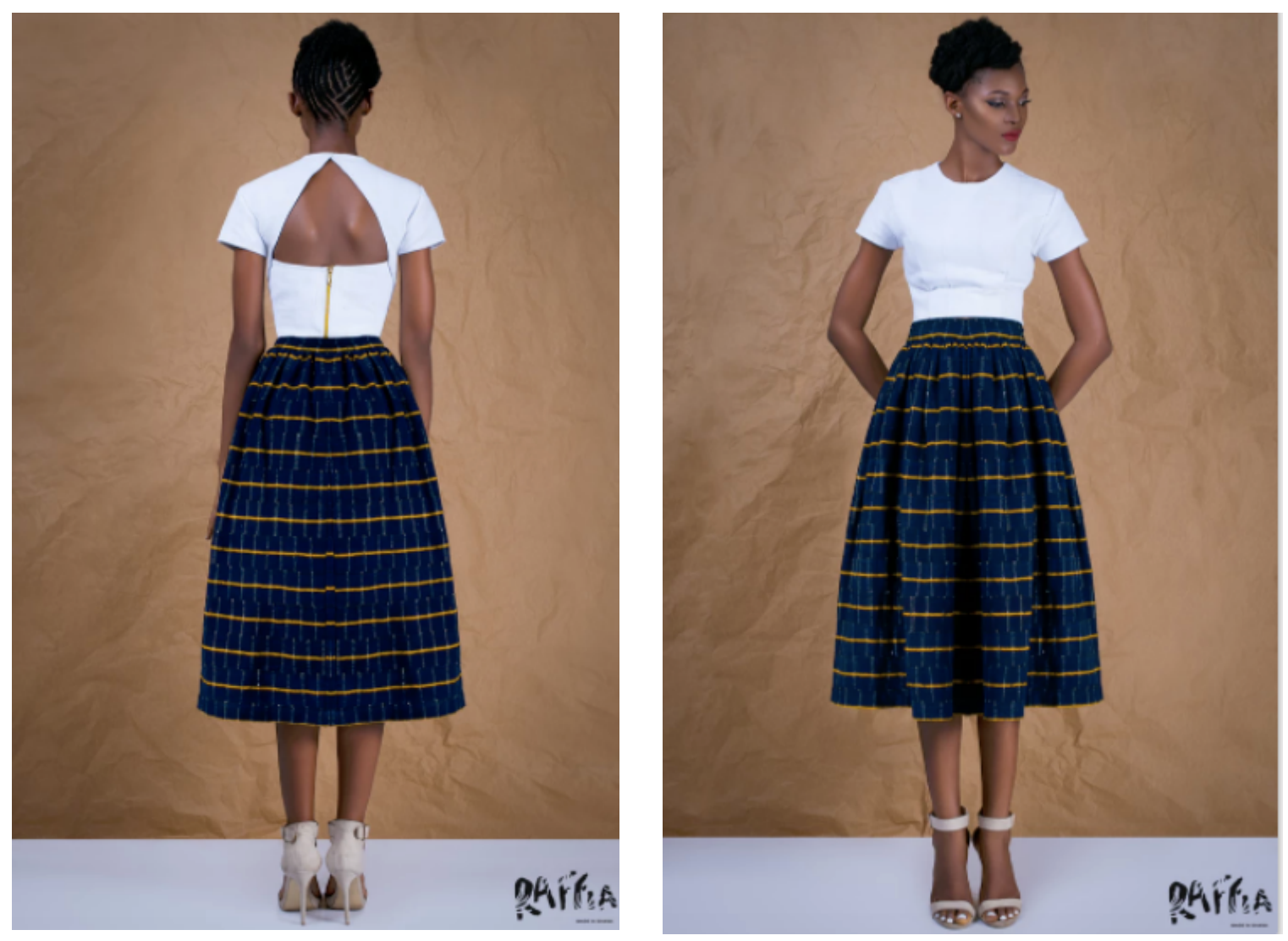

Bisha Gathered Skirt by Raffia Clothing. Photography: Charlene Asare. Model: Angelina Yakubu. Styling: Madonna Kendona.

\section{Supply Chains and fashion networks}

Despite a positive economic trend on the continent and an increased interest in West Africa's tourism, Ghana and Nigeria both maintain developing country status, and face constraints associated with low yearly incomes, infrastructural disadvantages and access. The African Growth and Opportunities Act (AGOA) developed in 2002 was an incentive aimed at boosting trade between Sub-Saharan Africa and the US (including textiles and clothing) and to achieve economic independence (Kunz \& Garner 311). The AGOA has 
been cited by a few of the designers as providing positive impact on their businesses. The entrepreneurs participating in the research are in a more advantageous position than the average Ghanaian who earns, on average, \$1480 US in annual income (World Bank Group). That said, some of the participants, including Madonna Kendona and Nana Osei, maintain part or full-time employment elsewhere in order to support their entrepreneurial endeavors, and as such, are in a unique position to understand some of the struggles associated with a precarious workforce, supply chain issues, loan acquisitions and rent among other business-related considerations.

Among the designers interviewed, the majority has approximately 1-5 full-time tailors that work in their atelier as well as external suppliers who are contacted when needed for items such as fabric printing or weaving. Finding trained tailors who will not abandon the work and provide consistent quality that satisfies a broad market proves to be one of the greatest challenges among the designers. Attrition rates are particularly high among tailors, who, for the most part, desire to run their own shops. Designers require accuracy and consistency in their garment construction and across items in order to meet international demands. For some of the tailors that are employed there is a burden associated with being re-trained in their craft when they could become a business owner instead. As Kendona sees it:

In terms of tailors, in particular, most people set up a kiosk somewhere and have their loyal customer base that come to them and so having somebody who has a skill that's good enough to make clothes for an international market, who is willing to work for you is difficult because by the time someone has that sort of expertise, they want to work for themselves.

For many of the designers, this means that as well as learning how to run a new business, they are having to adapt their relationships with their team. After seeing her seamstresses leave after only a few weeks of work, Dzidzienyo had to adapt her approach:

Most of the seamstresses learn through apprenticeship and don't worry about the quality. For them, they stitch the line and the sides and what it looks like on the inside is not their problem. So, it's frustrating for them if you insist on meeting a certain standard. I always unpick and redo, unpick and redo, unpick and redo... It will be very difficult for people to work with you for a long time in the industry. 
You need to be there and provide constant supervision for them to get it right. I have a lot of cases when they come for a week or two or maybe a month and they're out. So now I talk to them a lot. I tell them what the client says and what that translates into. If they're more efficient at work, getting it right the first time... If I'm doing a show I walk them through the process and let them know I want to grow with them. That way, they are more willing to put in the effort, to give more.

For Afriyie-Kumi, finding consistently strong weavers is not her greatest challenge, as she is regularly impressed with the results from her team based in the North. Her challenges are largely centered on infrastructure. When the brand was in its infancy, Afriyie-Kumi needed to travel 12 hours North by bus to find weavers to construct the first stage of her bags. In order to establish better means of communication, she needed to learn the language of the weavers who speak Frafra while she speaks Twi, the language most widely spoken in the more Southern regions of Ghana. Weaving is restricted to sunlight hours as electricity is scarce in the villages she works in and Internet is unavailable outside of the main town. Design sheets need to be sent on a public bus to reach her weavers while she remains in Kumasi, where she can be found adding lining and various finishings to her bags. If there are any mechanical difficulties on the bus, her order is delayed. As Afriyie-Kumi explains:

Everything has to be done in advance. An order cannot come through today and tomorrow I send it out, it's impossible. All of these barriers slow down productivity. Something that is very easy to do in the developed world, you know, with a click of the mouse you can send information. I have to make phone calls we have to talk a lot on the phone. I rely on my phone 24 hours a day to communicate with the weavers.

Similar barriers are reported by Hassan Iddriss, Creative Director of Hazza Underrated, who divides his time between Accra and Kumasi (250 kilometers north west) where his production of deconstructed second hand clothing is based). "My phone is my computer, my everything," Iddriss reports. "Internet is a bit messed up. You'll try to do your research and it will not be working or it will be so slow...so it slows down your work." 
As with any young company trying to grow their business, deciding when and how to grow production can be a daunting move forward. From production costs to finding dependable and cost effective factories to produce a growing fashion line can help or hinder a young business. Stefania Manfreda wanted to move her t-shirt production from a factory in Israel to Ghana but has yet to see it as a viable business move. While there are a few factories serving businesses in Ghana, some designers are not seeing their rates as competitive enough to make the switch from a foreign-based factory to a local one:

They are not even running at $20 \%$ capacity. I went [several years ago]. I went again a few years down the line, back to the same place to see what we could do because I really wanted to move production here. Well, same thing. You have to buy your own fabric and I don't need to go buy bails of jersey or cotton fabric to do t-shirts when it's the simplest thing you can produce and sell anywhere on the market for yourself.

Manfreda perceives the issue as a case of risk adversity. Few factories want to absorb the cost of buying bolts of fabric if they don't have existing orders, leaving the responsibility and risk with the designer. This tendency could be a contributing factor to what Kunz and Garner refer to as the embryonic state of the Sub-Saharan textile and apparel export industry, which in 2001 hovered around 1\% of world exports (310). They further state that despite its positive incentives, AGOA trade is quota-free, which may help small businesses in the short term but could hinder industrial growth and investment (312). “The other challenge is fabric. Materials," says Dzidzienyo, who produces her work inhouse, contends with issues of fabric supply on a regular basis, and considers how to produce her own. The local market is replete with fabric vendors selling small runs or left over bolts not previously sold. If a designer makes samples with one fabric selection it might not be available for purchase once sales are made. "It's a big problem. It's terrible," Dzidzienyo laments:

Sometimes, the worst part is when [customers] are willing to buy everything off of you, you go to the market to buy the fabric, but you can't find it anywhere. Even the base fabric, the plain cotton is a problem. So with this collection, after I did my samples and the photo-shoot, I went and bought yardage upon yardage of plain 
fabric. Even that, I wanted to buy 300 yards and the last 100 yards was a hustle. We ran out, they checked their warehouse, they ran out we roamed around the market for almost a week before we found the last 100 yards and when we got home we realised the quality was a bit different. They can't afford to buy bulk because they don't know if people are going to like it and buy it. They buy lots of different rolls in small quantities. Sometimes you go back within the week and it's sold out.

At Elle Lokko, Manfreda stocks multiple designers and sees supply issues across the board but especially for those entering the industry. "They bring me a whole stock in one go and I won't have any stock for two months because there is some kink in the production line and they can't sort it out immediately. I mean they are all upcoming brands. Some of them are still trying to figure it out." Participants collectively expressed a learning curve in contending with the precarious production process but that currently, after periods of trial and error, are better positioned to have more reliable runs. While any business will face teething issues, consistent barriers in production can hold back young businesses where startup and maintenance costs run high.

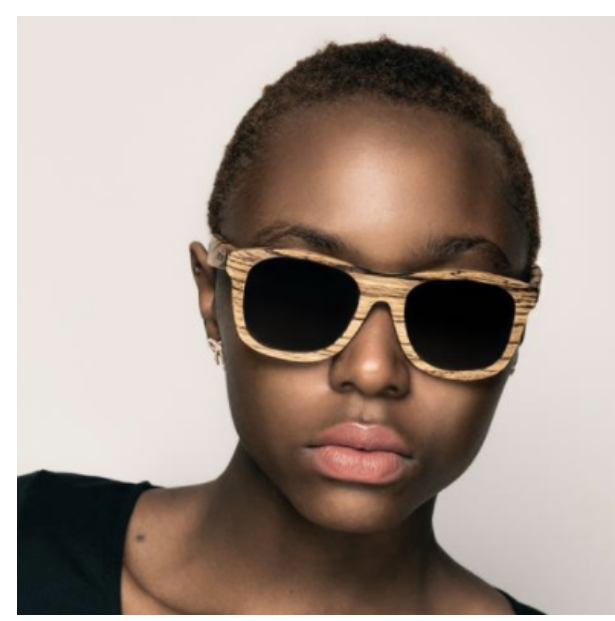

Barkdale Collection in Zebrawood. Image courtesy of Bohten

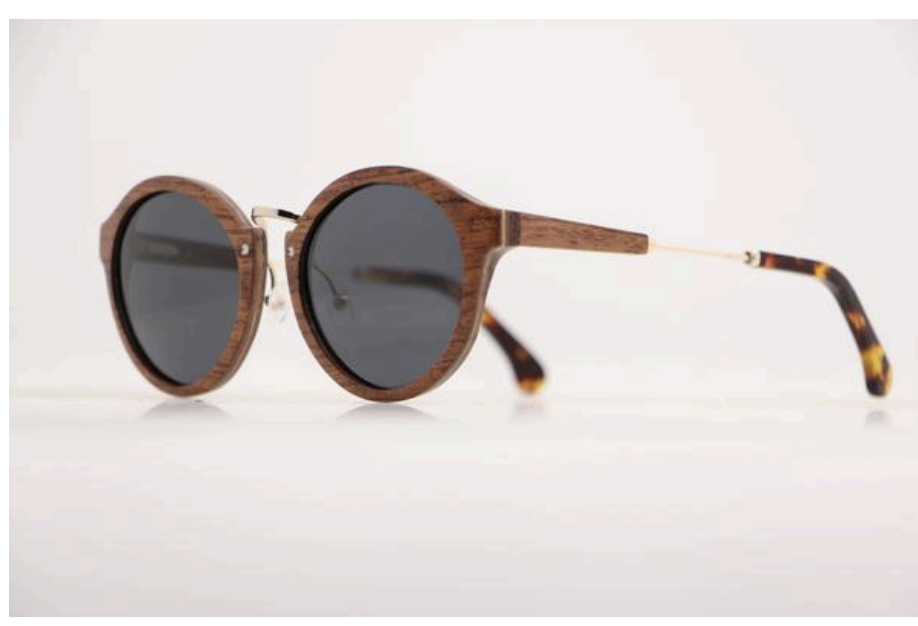

Odei Rosewood Tortoise. Image courtesy of Bohten.

Nana K. Osei and Nana Boateng Osei of the brand Bohten (pictured above) are manufacturing and assembling their sunglasses and accessories between a factory in Canada and Japan while plans are underway to move some of the production to Ghana, 
"Our initiative to manufacture in Ghana is on course; however, the current demand for product on a global scale is much too big for a start up to afford." Whether they move all manufacturing to Ghana will be cost, time and infrastructure dependent, but as Boateng states, Ghana has been vital to the development of their young brand: "Tailoring the concept in Ghana while capital expenditures are low is crucial to success in markets where labour costs are higher and there is less room for mistakes, as in Canada." What will be imperative for Ghana's development in the garment industry is for designers to be able to run all operations from start to finish within its borders and not only within the incubation period.

Fashion networks are becoming more prominent in the city of Accra with Ghana Fashion Week offering designers an opportunity to apply to showcase their work annually. Information platforms like African Fashion Guide, based out of the UK, run conferences across the African continent and beyond to offer advice to those wishing to start or expand their fashion business on the continent. While these services and opportunities offer the chance of connecting with the local fashion community, those interviewed expressed knowledge gained through practice rather than benefitting from systems in place that could protect new entrepreneurs and help with trouble-shooting. With or without a large influx of capital, production remains precarious and isolated experiences will not always travel through networks to assist in knowledge sharing. While some designers might have a desire to impart their better business practices among their community, others, who find better ways of contending with production, do not always have the same willingness to divulge information because of the risk of giving up their competitive advantage. This competitive advantage, of course, is centrally related to aesthetics and branding which the participants were keen to talk about. 


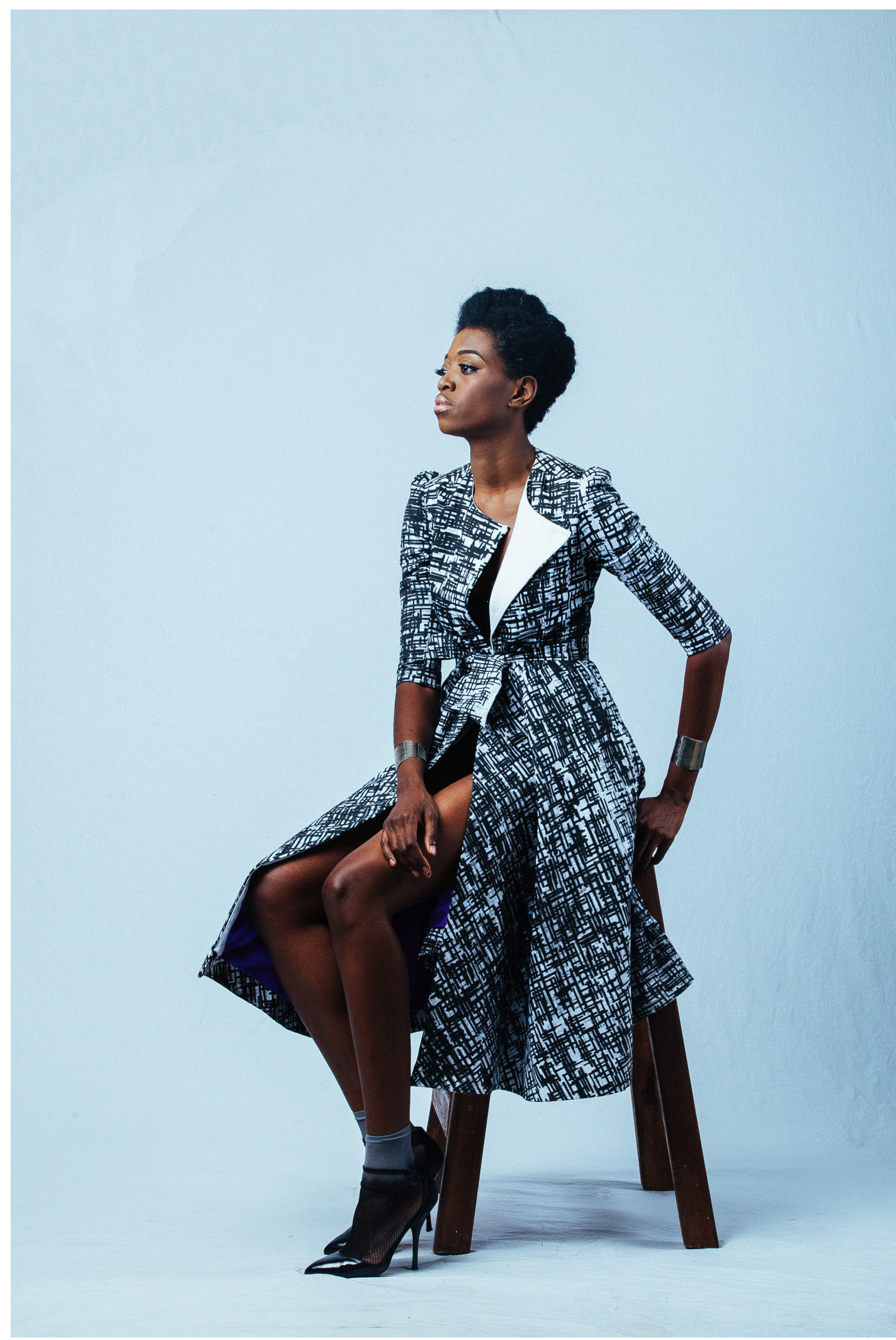

Ameyo Clothing modeled by Yaa and photographed by Ofoe Amegavie. Photo courtesy of Ameyo Clothing. 
Branding, representation and aesthetic considerations

"The weather and the colours and the people and the smiles," Akosua Afriyie-Kumi answered when asked about the main inspiration or influence on the design of her brightly coloured bags made form woven raffia. When she lived in London, England, she had the idea of starting her own brand, but it was only "when I came back to Ghana that I was bold enough to put yellow on a bag and if I lived in London I would have just used blacks and greys and naturals but being here helps me to go crazy with colour because I see all of these women with clashing prints and they just look amazing." The brightly coloured buildings and diverse flora that include bougainvilleas and orchids seen throughout the South offer a great divergence to the long winters in parts of North America and Europe and are a central inspiration for the participant designers. Madonna Kendona cited the fuschia coloured flowers in her environment as an influence behind her SS 2017 handwoven skirts.

For both Kendona and Afriyie-Kumi, geography also factors significantly in their production process as they both employ trained weavers (fabric and basket weavers, respectively) in Northern Ghana for their labels. Raffia palm, the material used to make AAKS bags, is grown in the south and sent to the North where it is dried and dyed using natural plant dyes. Traditionally woven baskets can be found in markets across the country but it is the contemporary shape, colours, lining and finishings that are evident in the AAKS label that has moved the traditional weaving technique into a new direction. When Afriyie-Kumi started her business, she wanted the brand to consist of bags that people could travel with, "as you couldn't travel with straw bags." She continues:

I wanted something foldable, something a bit flat that you can fit in your suitcase and that's how it all started. I sourced my raw materials from the south of Ghana and Kumasi and surrounding neighbouring villages and towns-from lots of different farmers actually. It's quite seasonal the raffia in Ghana. Normally raffia is used for stringing beads and tying animals. 
Madonna Kendona's brand Raffia uses hand-woven cloth and is another example of how designers are making clothing that appeal to a broad market while gesturing towards local craft and expertise. Originally from the Upper East Region, Kendona returned to Ghana with a Master's degree from Columbia University and a desire to start her own fashion brand. Identifying an opportunity in hand-woven cloth, traditionally used to make celebratory smocks called batakari, Kendona returned to her Northern roots to find cotton weavers to make cloth for her line, as she explains:

The batakari is actually the name of the smock, which is the ceremonial garb that men wear and it is designed in a way to make dancing look attractive. When a man wearing a smock turns around it sort of flows. So the fabric itself is called the Gonja cloth but the word batakari has been associated with the textile for so long that people just use the work batakari.

While Kendona and Afriyie-Kumi offer brightly coloured feminine options using craft-based techniques that are specific to a local context, Bohten started by Nana K. Osei and Nana Osei Boateng produce laser cut sunglasses made of West African reclaimed wood mostly sourced from the Ivory Coast. The eyewear comes in different shades of natural and painted wood from light brown to black and accommodates personal engravings or messages along the arm. While Bohten sells their products worldwide the fashionable accessory is suitably influenced by persistent sunshine and a warm climate that produces temperatures between 26 and 43 degrees Celsius (Ghana Meteorological Agency GMET). Climate can provide inspiration that is both practical and aesthetically driven, complimenting the immediate environment. Local influence stems far beyond climate considerations, however, such as Hazza Underrated drawing on clothing markets to assemble gender non-specific lines.

Self-taught designer Hassan Alfaziz Iddriss began his fashion label, Hazza Underrated, using vintage and cast-off clothing largely from Europe and North America and sourced from local markets. As of 2001, Sub-Saharan Africa was receiving 30\% of the world's used clothing exports, with the US being the largest exporter (Hansen 42). Used clothing exports from the US are categorized into four groups, with the best quality and intact garments going to Asia and Latin America and the remaining going to Africa (Kunz \& Garner 314). Hansen notes that vintage and secondhand shopping in the United 
States is not a fashion need but a pastime (40). This is arguably no longer just typical of the West as fashion entrepreneurs with disposable income have been modifying or reselling market garments for a number of years. For those that can afford to have excess garments, secondhand markets can lead to an extended wardrobe or lead to a business opportunity. Taking inspiration from Yohji Yamamoto, Iddriss deconstructs and redesigns items, which he hand-selects and reinterprets to make garments that are heavily influenced by 90 s street style. More recently his collections feature designs using vintage fabrics and hand-painted motifs that were a result of a collaboration with a local artist. The result is a collection of unique, one-of-a-kind pieces, which he deems as "casual luxury". Luxury is a term widely used among the entrepreneurs but does not seem to connote one fixed meaning or price point. However, as Stefania Manfreda discovers below, there is a perception of luxury that is perhaps different to that more commonly experienced in the West.

At Elle Lokko, Manfreda stocks her own line of t-shirts as well as clothing and accessories that are made in Africa. Having spent several years studying and working in Italy, Manfreda returned to her home city of Accra to open her shop in the lively neighbourhood of Osu. According to Manfreda, most shops in Accra lacked a high degree of presentation to draw customers in. Recognizing an opening in local fashion retail that had not been addressed she stated:

If you go around [Accra] you see a lot of shops don't have windows. They don't do settings or displays. It's only now happening. So people are getting into that mindset of having a retail store. I opened Elle Lokko in 2008 and because I come from a design background and I did the space to look a certain way, people were shocked. People were like, "Oh it feels like I'm abroad." But everything in the shop was from Ghana.

Some residents would confide in Manfreda that they were too intimidated to enter the shop and assumed the price-point would be beyond their budget:

I thought well... I don't want to have the prices in the window because I think it's tacky to do that, but I guess I need to communicate to my audience in one way or another. So yeah, you have people who are intimidated like that. There are some 
people who won't walk into a certain bank because it's "too nice," like "I'm not allowed to go in there." I guess it's an old colonial issue. It's all there.

For some Ghanaians, as Manfreda asserts, the boutique represents an aesthetic that is associated with international travel, luxury and cosmopolitanism. To others, the boutique may not be immediately representative of a familiar space in which they feel they belong. The issue to which Manfreda refers, points to the lasting affects of Accra as a colonial capital (Ray 507) - the age of slavery, British Rule of the Gold Coast followed by the building of an independent state. It is important to note here, the term Afropolitanism popularized by Anglo-Ghanaian-American Taiye Selasi in her essay Bye-Bye Barbar, in which she describes the term as "They (read: we) are Afropolitans - the newest generation of African emigrants, coming soon or collected already at a law firm $/ \mathrm{chem}$ lab/jazz lounge near you. You'll know us by our funny blend of London fashion, New York jargon, African ethics, and academic successes." As Rovine states: "Afropolitans also think critically about what it means to be African in the midst of this "inbetweenness" (248). Cameroonian philosopher and writer Achille Mbebe uses the following definition: "Afropolitanism refers to a way — the many ways - in which Africans, or people of African origin, understand themselves as being part of the world rather than being apart" distinguishing it from Pan-Africanism which he describes as a racial ideology (Mbembe \& Balakrishnan 30). Many of the participants have lived what they may or may not describe as an Afropolitan lifestyle, having worked or studied abroad, now returning home among many of their peers to establish themselves as entrepreneurs. These entrepreneurs are in large part redefining the cities they have returned to, bringing personal experiences, supporting their local economy and blending aesthetics which are a merging of local and global. It is not just those that have studied abroad, however that are changing the fashion landscape. Designers like Dzidzienyo, who have studied and apprenticed within Ghana, are highly attuned to the local market and are also adding to a diverse fashion landscape.

Following a period of training under numerous fashion designers in Ghana, Dzidzienyo opened her own shop. By focussing her creativity on producing innovative fabrics, her line is distinguishable not just in cut but also in material. In her latest 
collection, Dzidzienyo used Adinkra symbols representing beauty and leadership from the Ashanti people:

When I started, I was doing custom pieces so it was what the client wanted. I started doing collections in 2013. The first ever collections, we didn't make our own fabric, we used fabric from the market but the concept of the designs remained the same - playful, fun, clean lines. Now, the identity is more about the fabrics. When you see the fabrics you see that they are not on the market. Usually, I pick a concept and then I design the fabric to suit the concept. I use motif sometimes that have to do with the concept and then sometimes blend it with the adinkra symbols. So usually anyone that sees the collection they recognize that these fabrics are handmade and are different - you can't find them at the market. Apart from the novelty and individuality that emerges from designing and manufacturing her own fabrics, Dzidzienyo chooses to do so, in part, out of necessity. Using ready-made fabrics from the market or store can expose her work to copycats who will make and sell her designs at a lower cost and quality to turn a quick profit. Alternatively, fashion seekers might photograph a garment they like and bring it to their tailor who will make it for less thus cannibalizing their own fashion industry. For designers like Dzidzienyo this is one reason for not using Dutch-made Vlisco fabrics or their alternatives known as Ankara, African or fancy prints.

It's easy to take pictures or download pictures from designers - they [customers] like it and want it but they feel like if they go to the designer it will be too expensive. And if it's African fabric it will be all over the market. They will go and get the fabric, they take it to their seamstress and get the exact same thing made and you see your clothes being worn all over the market but you're not making any money.

Iddriss echoed similar imitation concerns with his line:

...imagine if I create a design with Vlisco. People are going to buy the fabric from Vlisco, show up and sew the same styles that I've produced which means it's not going to help me...

He has also seen extensive use of the fabric in recent years: 
We are all creative individuals walking this earth...but my problem right now is that most designers are using African print and when you go see their stuff you can see they are not really their own designs. Like, maybe you saw it from Gucci or Valentino and they will create the same thing with African print and call it their design! That's copyrighted, you get me?

Ankara prints have, in recent years, grown in popularity abroad and among a younger generation. Delhaye and Woets (2015) discussed the popularity of wax print among some Ghanaian designers as a way to connect fashionable, middle-class Africans both within the continent and among the diaspora who perceive the fabric as part of their heritage (86). "Wax cloth has been an integral aspect of fashion in West Africa since the late nineteenth century. ...Wax cloth fabrics are worn at ritual events such as funerals, weddings and name-giving ceremonies and also function as a valuable gift and part of a dowry" (87 Delhaye \& Woets). Throughout the city of Accra, women can be seen wearing Ankara prints but it is by no means universal. The designers participating in this research are not currently using wax prints for a variety of reasons both practical and cultural. Dzidzienyo has seen a generational shift throughout the last few decades where Ankara print has become favoured among the youth:

African print is all over the place now. Before, I remember when I was in school, to get people to wear African print was very difficult. It was the adults - our mothers. For you to try to convince the youth to wear African print was almost impossible. They wore it to church and they wore it to funerals.

For Madonna Kendona her reasons for not using the material stem from cultural origin. When asked if she would ever use the Ankara print in her collections she stated "It doesn't have its origins on the continent and so it doesn't really go with what Raffia stands for which is authentic, traditional methods used to make contemporary clothing." Afriyie-Kumi shares a similar appreciation for products that stem from a more localized craft while underscoring the tendency for African designers to be placed in association to African print:

Normally, I wouldn't really use it in my products. I think they're beautiful and it's really well made but it's not the vision I have for my brand and I don't want to go down that route because I feel everyone is doing it and I don't want to be under 
that umbrella of 'Oh! Next to that African designer!' being pushed into that.. Does that make sense? Not that I'm trying to stay away from it, but I have another vision in my head when it comes to African products that it doesn't have to be African print-- it can be something else. It can be products made with other materials from Ghana without it being necessarily African prints so that's where I'm going with mine.

Comments like that of Afriyie-Kumi, Kendona and Dzidzienyo underline the unique approaches and attitude towards what they deem to be traditional and how they develop their brands under the umbrella term "African Designers". For many entrepreneurs, living and/or studying abroad and returning to their first home has provided unique challenges and opportunities that have added to the complexity of their work both in aesthetics and production. As Nana Osei says: "I'm a Ghanaian who has lived in New York, South Africa, the UK... I consider myself a global citizen. I think people are getting comfortable with this dual identity that a lot of Africans have and that's what you're seeing". Others, who have chosen to study in their home country, are finding unique ways of diversifying their collections through their in-depth understanding of local style, fashion commerce and competition. 


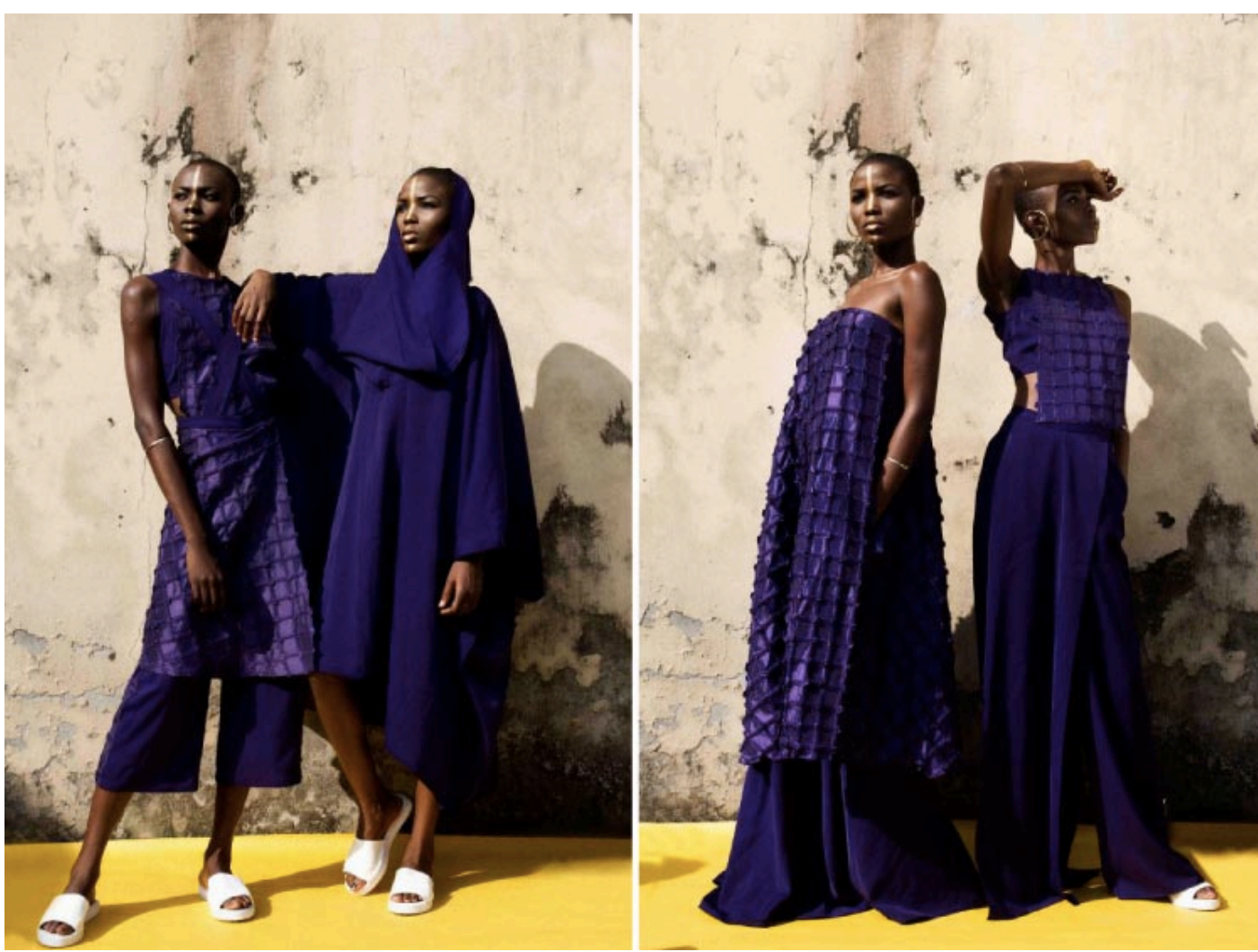

IAMISIGO SS15 Taboo Collection. Photography: Lakin Ogunbanwo. Models: Cynthia I. and Cynthia O. 


\section{Chapter 3 \\ Case Study 2: Tracking Nigeria's flourishing fashion industry and the key opportunities for sustained growth as highlighted by Nigerian fashion entrepreneurs}

East of Ghana and beyond the borders of Togo and Benin along the Coast of Guinea, lies Nigeria. According to the International Monetary Fund (IMF), Nigeria is Africa's most populous country with the largest economy due to its productive oil extraction industry. The port city of Lagos is a bustling metropolis that experiences unceasing traffic jams along the many bridges that connect the mainland to the multiple islands dotted along the coast. While Nigeria's capital of Abuja lies at the country's centre, fashion-wise, Lagos boasts the largest number of high-end boutiques tucked behind gated doors. In the neighbourhoods of Victoria Island and Lekki are beautiful boutiques like Temple Muse, Alara and Stranger, all housing local and international fashion brands. Just as in Ghana, Nigerian designers report impressive growth. Participant Bubu Ogisi, Founder and Creative Director of Lagos fashion brand IAMISIGO, reports that over the past five years, "Lagos Fashion and Design Week [has been] improving, getting more and more buyers coming in, more and more visual support outside." If properly groomed or trained, Ogisi feels that Nigerian talent "can probably surpass the international standard. It's probably just a matter of time."

Adebayo Oke-Lawal, Founder and Creative Director of fashion brand Orange Culture, attributes rising interest in Nigeria's fashion to the level of creativity emerging from the African continent: "I feel like as a young designer, we're lucky that we discovered the opportunity now and discovered it at such a key time. People are so interested in what Nigeria is doing or what Africa is about and I feel like Lagos is so important because all of our inspiration is drawn from here." While Oke-Lawal sees a rising global interest in Nigerian brands, the major changes that are occurring in the fashion industry on a local level are part of a worldwide trend. "Fast fashion is popping up all over the place. Designers are starting to sell off the runway because it's not the way that it used to be." The downside of this change is a profound sense of instability across the global industry. As he explains: "The industry is having to change whether we like it 
or not. We're having to create new ways to sell, we're having to market in new ways, we're having to produce in new ways to give people the opportunity to afford new clothes without dying." The interesting focus in this Nigerian participant is the understanding of Nigeria within a larger global and competitive fashion system, whose pressure is deeply felt: "There is a convergence of the industry worldwide where all of us are almost targeting the same space and buyers are beginning to look at us all as relevant."

Enthusiasm for African-made design as seen in international press does not resonate the same way among all entrepreneurs. Joseph O. Ike and Ola Akindeinde are Co-Creative Directors of the menswear brand JZO based in Kaduna, North Western Nigeria. To Ike, there is a disconnect between the perceived level of success of Nigerian brands and what is happening on the ground. Further, Ike feels that representation tends to be skewed, leaving many voices within the Nigerian fashion industry going unheard.

I think the media's metrics for success when it comes to brands in the Nigerian fashion industry are silly. You're a successful Nigerian designer when you showcase your collections at London Fashion Week, or New York Fashion Week, or you're featured in Vogue Magazine (on some obscure page). Don't get me wrong; it's fantastic to show at these international fashion shows, but the real measure of successful fashion brands everywhere is their commercial success and viability. Over the last 5 years, we hear about rapid development in the fashion industry in Nigeria, but take a closer look...it's the same set of people that are constantly featured. The same set of people who get grants to attend fashion shows in London 'cause there's a slot for an emerging designer from Africa, "and since we had him/her last year, let's stick with that.

For Ike, the future of Nigerian fashion is laden with possibility that can only be accessed and flourish when systems are in place to support it: "development of the fashion industry is strengthening the value chain, so that the "industry" is commercially viable, so that it can compete fairly on the international stage. To do that, what we need is strategic investments in every sector of the value chain, from raw materials to light manufacturing." With better systems in place, Ike feels Nigeria will be better served to grow its industry, at which point profits will be the true signifier of success: "When a 
designer is tagged "successful" it should mean "This person built or operates a corporate structure that brings these compelling designs to the market in a profitable way!" While not every aspect of the value chain is receiving due investment, a growing number of young people are entering the industry. Kunmi Otitoju, Founder and Creative Director of the accessories brand Minku, refers to the large number of Nigerians who study abroad and return home to start a business and how that can often translate into innovative methods of production: "Many people get an education from the UK or the US and they learn about design but then all the materials and the machinery to make those things happen in the Nigerian space are not readily available." Without the proper tools and infrastructure, entrepreneurs are forced to identify alternative methods that work for them that will help propel their design ideas forward. What is frustrating for some designers offers unique opportunities for others. As Otitoju states, "They are using the theoretical knowledge they got from their university education in some other countries and using what is locally available or locally normal to create new things, and that is creating a really interesting space of objects."

Just as we saw entrepreneurs use alternative fabrics for their lines not often found in the West, Nigerian designers like Tunde Owolabi are reimagining how locally woven fabrics can be used for accessories and footwear. Owolabi, Founder and Creative Director of fashion brand Ethnik, is a trained photographer and graphic designer who started a Lagos-based brand from locally-made aso oke and leather sourced from Northern Nigerian tanneries. Having studied in the UK, it was not until he was back at home that he felt he could grow the type of business he had envisioned when he was living abroad. As he puts it: "There was a lot of room for innovation but the kind of innovation that I was looking for had to resonate with my culture, and I needed to be at home and to be part of what was going on here for me to be able to create something original. The opportunities for designers at home are not only materials based. Understanding business networks, information flow, and personal connections can make all the difference in early stages of a business."

This exposure to the west has also been beneficial to Uchechi Egele, Founder and Creative Director of fashion brand Marté Egele. Egele studied fashion in the US and worked for a number of American-based brands following graduation. When she began 
showing an interest in starting her own fashion brand, she heeded advice from her father about the advantages of launching a business at home: "My dad was always telling me that there is a glass ceiling you can never get past if it's not your own country. And I thought, ok let me go home and see what I can be. I plan on being a global brand and not just staying in Nigeria. But I thought, let me go home and understand the industry there, be with my parents, meet people..." Despite these advantages, growing a business in a developing country presents a number of obstacles that might not have been present when the designers lived abroad, as discussed among Ghanaian entrepreneurs. For Owolabi, the greatest mechanism for economic growth within the continent is if entrepreneurs are able to gain traction, thereby feeding resources back into the local economy:

Africa is now... If you enrich Africa by enriching the entrepreneurs here-- the designers, the artisans -- that's when you are really talking about poverty alleviation. If you are supporting the businesses and you invest in them, then you are actually alleviating poverty and helping Africa to stand up on its feet. Supporting the growth of creative industries is gaining more attention from United Nations Conference on Trade and Development (UNCTAD) and UNESCO. Their research reveals that developing countries should be leveraging their cultural assets and integrating them into global economic networks in order to promote job creation, growth and new revenue streams (Lobato 338). This theory is supported by many of the designers including Ike, who states: "It's very important to us, that we - Nigeria and other African countries - are seen less as foreign aid destinations, and more as foreign investment opportunities and partners." With greater investment, designers would be better positioned to contend with some of the key obstacles in their production and distribution processes, as outlined below. 

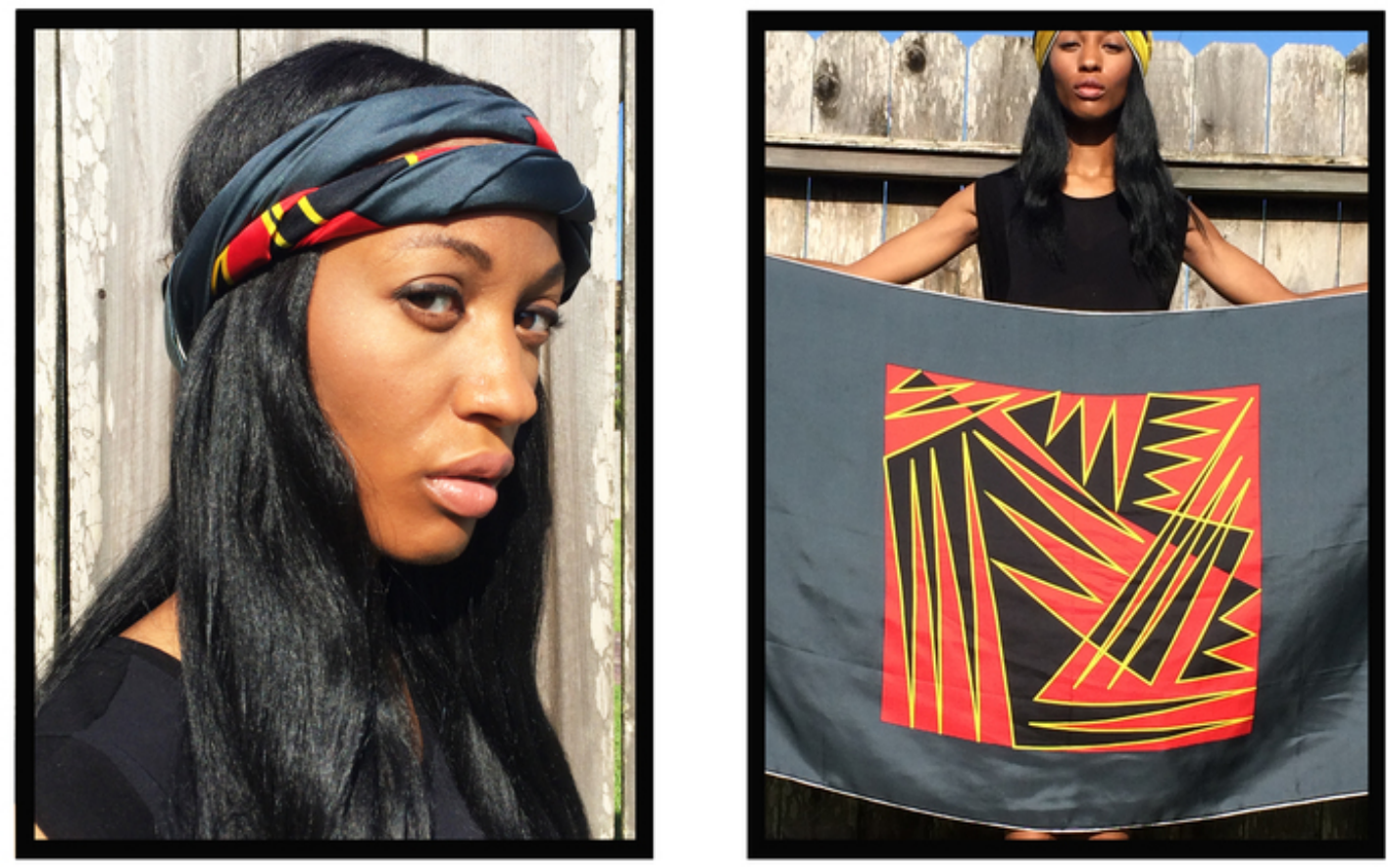

Marté Igele "Boxed Up" scarf worn by designer Uchechi Egele. Photo courtesy of Marté Igele.

\section{Garment and Accessory Production \& Distribution}

Despite their many differences, the participating Nigerian entrepreneurs cite similar constraints to those in Ghana with regards to growing their business within and beyond their country's borders. Shipping costs, locating trained tailors, paying for power supply and contending with power cuts are all too familiar to those in and outside of the main commercial hub of Lagos. Power cuts are a daily reality for forty percent of Nigeria's residents and business owners, while sixty percent are not connected at all, largely affecting the county's overall social-economic and technological development (Aliyu, Ramli and Saleh 334). Ogisi, who runs a studio and a showroom, cites the recurring power cuts as a continuous burden on her overhead and daily operations:

We have to have two forms of power supply. We have to have the actual power supply (which they 'have' to supply all of the time... which they don't!) and then you have your own man-made power supply, which is the generator. But that 
comes at a cost - you have to maintain it, you have to buy diesel, which is twice the price of petrol...back home and at the studio and here at the showroom, there is a cost.

Echoing Ogisi's concerns, Egele cites a growing use of solar energy as a way to bypass the power supply issues:

It can slow things down because when there is no light or diesel you come to a halt and [you're] not able to finish work on time. So yes, it does take a bit of a toll and maybe with the artisans that you are leaving your stuff with, their sewing machines might run on diesel. But there are solar panels now, which is kind of helping people to power their workspaces.

Beyond power supply, Nigerian designers also shared the crippling costs associated with shipping finished products within the continent and worldwide. Some designers in Nigeria, however, have found local start-ups that are beginning to provide more competitive rates than the major shipping companies like DHL. But while these startups are providing some relief, prices are not competitive enough to avoid the circuitous route of asking friends and family help with distribution who, when travelling, are willing to pack products in their personal luggage. Oke-Lawal gives insight into the convoluted shipping methods he uses for Orange Culture:

Whenever I want to ship clothing abroad we have to use the most ridiculous means to just get it to the customer; like we'll ship it to London and then ship it from London to America or to China because that's an easier or cheaper route than sending from here. So shipping is a huge issue! Even within the continent.

[Shipping to] South Africa is more expensive than shipping to England. Owolabi echoes Oke-Lawal's concerns for the shipment of his products at Ethink, as he currently has to "depend on people travelling or people that don't mind paying to get the product to them." The costs, he says, are one of the largest impediments of accessing international markets. "If you bought a pair of shoes for $\$ 100$, it would probably cost me $\$ 60$ to send them to you. So, you know, it's a huge challenge. If I'm not able to cater to customers across the continent, I can't fulfill my dream of being a truly international brand." 
Power supply and shipping costs are just a two examples of infrastructural challenges and logistics with which entrepreneurs contend and force entrepreneurs to improvise in their daily operations. These challenges notwithstanding, there is a growing presence of garment factories across parts of East Africa including Ethiopia and Kenya, counting H\&M and Primark among the customer base (Berg et al, McKinsey \& Company). Countries within West Africa, including Ghana, have also seen a growth in textile and garment factories but not all fashion entrepreneurs are accessing them for their labels. As outlined in chapter 2, some Ghanaian designers cited the lack of cost-effective factories in Western Africa as a deterrent to local production.

Conversely, IAMISIGO, based in Lagos, uses a combined effort of local tailoring and a factory based in Northern Ghana for ready-to-wear items. While knowledge sharing and access to industry information could be influencing factors in the use of factories, designer needs are not the same across brands, especially when looking at products as diverse as bags to footwear to sunglasses. Price-points, scale, target market and access to retailers will also dictate who can and cannot meet factory margins. Despite industry growth, factories have not reached market potential. Ike and Akindeinde have built factory needs into their business model with Garment Production Inc., a division of their JZO company that meets small and medium scale production needs. As Joseph O. Ike explains:

We believe that having production factories, like ours, helps with quality standardization. Designers and other fashion businesses who utilize our facility are assured of a certain quality product. And so we are slowly ensuring that the marketplace of Nigerian designers is being populated with standard quality products. As time goes on we hope to also begin to attract small and medium scale design outfits from other parts of Africa, USA, Europe, and other parts of the world who have typically seen Asia as their only production destination, to explore Nigeria as a viable alternative that gives their businesses an added competitive advantage.

Not all of the designers interviewed in Ghana are currently positioned to outsource to factories. Egele constructs each of her handbags in-house in Lagos with the help of local tailors, but envisions expansion in the future. For her scarf collection, however, she 
outsources production to China where the scarves come back hand-rolled. The reasons for outsourcing are simple, according to Egele, who says that it is faster, easier and cheaper to produce in China. Further, none of the local factories could accommodate her requests, and many would themselves outsource parts of production, adding unnecessary costs to her production. While she wants to position her company as a global brand and move production locally, the operation is not financially viable yet. Similarly, Otitoju makes luxury bags made from vintage fabrics, including aso oke which she sources from relatives or from markets. Otitoju, personally handcrafts each piece, treating each item as a sculptural project. For her, maintaining an artisanal quality in each item is one of her main objectives. She fears that using a factory might obstruct the quality. Tunde Owolabi employs trained cobblers to execute his shoe designs. He also uses aso oke in his footwear and sources his material from commercial weavers outside of Lagos.

Despite an existing commercial hub of weavers who produce fabrics for weddings and events, Owolabi states that contemporary weaving has lost some of its former intricacy, a level of craft he hopes to reignite among weavers in Ghana: "They weave commercially for events and all that but I wanted something different," he explains. "I wanted the guys to weave like they used to weave in the olden days. Then they had more intricate designs." Owolabi connected with a group of weavers about his design ideas and found that the challenge of making more intricate pieces has had a positive effect among the community:

They enjoy it more and they take pride in what they do now because their friends from other parts of the village come to see them, they ask them "who is giving you this kind of work to do?" and for them it's a sense of pride because they feel like they are doing something that's different from what everyone else is doing. Despite the positive impact on the weaving community, however, Owolabi is worried about what the future holds, as young people are expressing less and less interest in learning the necessary skills. Each design that Owolabi creates for his fabric demands a level of complexity that not all weavers have been trained for. Consequently, he wonders who among his best artisans will ensure that the craftsmanship and knowledge is transferred to the next generation. Finding trained cobblers to produce good quality footwear is more easily accessible than finding weavers who are willing to learn and 
produce enough of the high quality fabric that he needs. "I want to be able to scale up and would love to increase production but if I have to increase production, I have to increase the number of weavers that I have and get them trained to be able to weave to the capacity that we need." Finding the right team and investing time and energy in training is an ongoing reality for entrepreneurs everywhere, especially in regions like Ghana and Nigeria where informal employment is the norm. Meanwhile, designers have to ensure they are reaching a broad market using standard routes of marketing and communication as outlined below.

Once the research and development is complete and designers have found their team of artisans and production methods for their products, raising visibility for their brand among international markets can be challenging. According to Egele, a strong social media presence and online footprint helps in acquiring trust from international markets, and can assist in dismantling some of the negative stereotypes that can be associated to African made products. Egele says that visibility is key:

There is always a barrier when it comes to selling overseas because they haven't heard of you before and they think "ok, you're coming from Africa." You have to be on point when you're selling to them. They will check your social media and that you have your packaging right and that you have a means of distributing your products; my distribution needs to be on point.

Ogisi cites a similar barrier in accessing distribution opportunities because of an antiquated perception of what business in Africa looks like: "Some people still think we live in mud houses," she says with a laugh. Other prejudices include queries like these: “'Do they have the supply chain? Do they have the standard?' And when you say 'yes, this is where this is organized' they respond with 'no, no way.'"

These discussions of production methods and international perception present a cyclical pattern that can slow down an industry's development, where only a few fortunate brands manage to survive. Some of the designers have suggested that international press has helped legitimize them as a brand both locally and internationally. After being interviewed on CNN for his brand Ethnik, Owolabi received emails from customers who expressed an increased attachment to their purchase after having seen him on television. Similarly, Afriyie-Kumi from Kumasi, Ghana (discussed in chapter 2) 
rarely turned down an opportunity to be interviewed by fashion bloggers, and the accumulation of those interviews is what she attributes to her rising international visibility and connections. Providing a platform for designers to share the histories behind their brands and the techniques used helps in creating the stories and visual connections with their future customer base.

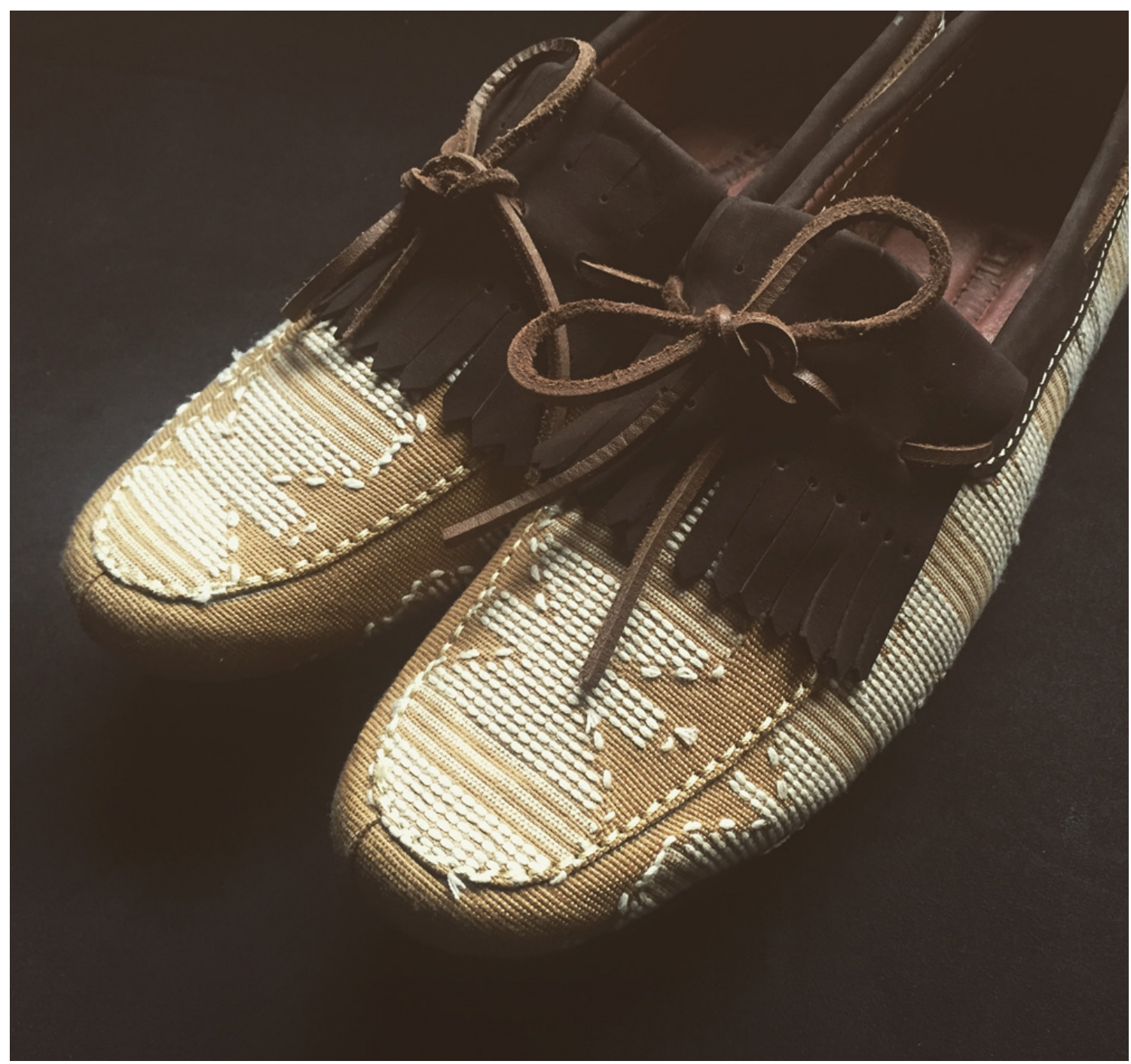

Footwear by Ethnik. Photography: Tunde Owolabi. Photo Courtesy of Ethnik by Tunde Owolabi.

Developing aesthetics in the context of material, gender and culture

As outlined above, many of the fashion entrepreneurs interviewed from Nigeria are showing their appreciation for locally produced materials like the aso oke, a Nigerian 
woven fabric sewn together in strips (used in Ethnik by Tunde Owolabi pictured above). Owolabi uses the woven fabric as a platform for storytelling, while Otitoju's combined love of aso oke and pastel tones are the reasons why she uses worn, vintage pieces to line her bags. Oke-Lawal uses aso oke as well as Adire - an indigo tie-dyed cloth for his pieces. Despite his strong ties to local, artisanal products and his creative inspiration taken largely from Lagosian life, he still receives feedback that his pieces are not inherently African because they are less commonly seen.

Some of our best sellers are Adire prints so we use a lot of Adire handmade pieces. I think that's one of our strongest points - all of our accessories are made here. All of the pieces are made here by local artisans. A lot of our prints are made here and we do a lot of collaborations with designers here. Even when we do digital printing here we make sure that the story behind the print is organically African. So all of our prints are things that we've grown up seeing.

Oke-Lawal's Orange Culture label is also known for its gender-neutral approach to fashion. Oke-Lawal states that while this sets the brand apart from others, this break from normative gender roles is not universally adopted. "We focus mainly on masculinity and the controversy that goes around masculinity within the African continent," OkeLawal explains, noting that the androgynous look is not readily accepted. "Acceptance was definitely a huge issue. Five years ago, it was like we were entering a desert with no water." Positioning a gender-neutral brand within a largely patriarchal society, where the socio-cultural system is dominated by male values (Attanasso et al 374) is no easy task. The growth of gender equality in Nigeria has largely been blocked by cultural and religious factors (376) and there are many reported cases of individuals have been persecuted for not abiding by hetero-normative codes and dress. Oke-Lawal insists that gender stereotyping is evident worldwide, not just in his home country. Breaking down expectations of gender dressing is at the core of his brand's ideology, not just in Africa but beyond; thus he passionately asserts that his focus is to use fashion "to combat those stereotypes and making people aware that there are different types of men. A man can be emotional and still be a man and all of these different things without his masculinity being taken away from him." 
Likewise. Ogisi's brand IAMISIGO challenges gender norms with pieces that she says are meant to be worn across sexes and generations. While running what is predominantly known as a womenswear brand, she has noticed more men wearing her loosely fitted garments. Although there is a global movement towards androgynous collections and style options, Ogisi reflects on her own culture and home city of Warri as precursor to some of her design choices, "Where I'm from, in Warri, the men wear wrappers, they don't wear trousers. You layer the wrapper actually. Layer it and then wear a shirt over it. There is nothing feminine about it, that's how everybody has to dress. So that's maybe why it's influenced me." In last year's SS16 collection entitled Modern Warrior, Ogisi reflected on the experiences, dress and strength of female Ashanti war hero, Yaa Asantawa (McCaskie 158), for her designs. This historical heroine "went against the British Colony in the 1900s and was a really, really strong warrior figure in Ghana." Like Joan of Arc, in available photographs, as Ogisi explains, "she looks like a man," meaning also that she is equipped with "jujus," or protective amulets. "When you go to war you need to have something on you - men back then they thought it was actually protecting you. But now with psychology and science you obviously know it's all in the mind just like today when you carry a good luck charm."

Like other designers in Ghana, Ogisi also uses materials in her immediate environment and up-cycles using tires she sources from the roadside, which she then paints and transforms into seating. For her AW 15/16 East of West Collection she took cues from the numerous fishing boats and communities that line Lagos harbour. She sourced fisherman's twine - a material described on her website as "traditionally masculine" - to make dresses and tops using a crochet technique. Otitoju, who divides her time between Lagos and Barcelona, gives each of her bags a Yoruba name and plans to translate her website into Yoruba to situate the brand and to add to what she says is a short list of websites that are available in her native tongue. Having travelled extensively abroad, she feels that the identity of the brand is strongly rooted in Lagosian life. Paradoxically, Otitoju feels that despite the Nigerian market being very supportive of her, the brand's image is too casual for a market that prefers to dress up more often than is typical in the West and in Europe. To help provide context behind her products, Otitoju incorporates descriptions with the bag, a practice also shared by Owolabi who includes a 
booklet with each pair of shoes to provide consumers with more information on their purchase and its origins.

In this Ogisi's practice is similar to Uchechi Egele's creative processes in Nigeria. Egele's bag and scarf designs are largely influenced by her personal experiences, struggles and achievements since returning to Nigeria. For the bags, she uses leathers that are indigenous to Nigeria, including snake, crocodile and calf. More recently, Egele says that ostrich leather has grown in popularity and as such, she tends to avoid it wanting to differentiate herself from other local brands. Despite tanneries in Northern Nigeria supplying to large brands such as Louis Vuitton and Gucci, tanneries have reportedly been on the decline in recent years and while large foreign fashion houses can purchase leathers in bulk, smaller local brands like Egele's do not yet have the capacity. Any scraps and remaining pieces are sold back to Nigerian wholesalers where brands like Marté Egele get their supply. This indirect flow of goods results in higher production costs and retail prices and for Nigerian designers, buying back locally produced items that have been made less valuable is understandably frustrating. This frustration extends to aso oke as well. As Owolabi insists, it is one of the only surviving fabrics that is truly Nigerian that in recent years been copied by foreign factories and sold at market:

That's like taking the food off of the table of those who actually created the fabric. Yes it's interesting but you can't take it away from the people. You need to keep it in the culture from which it originated. You know, and that's supposed to be part of our heritage - something that we keep for future reference and for people who are coming after us to appreciate that there was actually something - an art - that came from this particular culture.

By reinterpreting a traditional craft and providing written explanation of his work with his products, Owolabi maintains the integrity and connection with the fabric's cultural roots. Navigating markets that sell watered down, factory imitations of locally developed crafts is a trend that no participating entrepreneurs have been in support of.

Using crafts or techniques that are specific to a local context can have unexpected outcomes. Ike of the menswear brand JZO uses a variety of styles including adire. Recently, Ike and his business partner have seen sluggish sales of their line of men's 
kaftans among non-African diaspora customers. It is difficult to pinpoint the exact cause of lower sales. When asked to speak on the issue of appropriation, Ike stated:

I think there is a noble intent in the push against "appropriation", and that intent is to safeguard people's cultural heritage from being exploited by mainstream media, or devalued as trends or fads. I certainly support that idea, I think cultural ideals should be respectfully admired....I think this emphasis on "appropriation" may also have a negative consequence at the end of the day. Perhaps it's the businessman in me speaking but when someone wants something, and pays for it, especially where it is legal to do so, let's give them the benefit of the doubt.

Some of the fashion design choices addressed above offer unique approaches to traditional forms of cuts, weaving and/or dying or new approaches to more modern materials such as used tires, leathers and fishing twine. If a designer chooses to enhance the more traditional aspects of a garment or craft, considerations might be made for their viability within an international market, ironically in part, because of discussions that are intended to protect exploited populations. On the other hand, Otitoju discussed the issue surrounding non-African designers using African-made items such as aso oke for their collections. To her, the issue does not lie in the borrowing of objects but in the lack of acknowledgment and explanation of where it came. To borrow and remain silent about the origins insinuates intellectual ownership:

I think designers that use those influences act like their brains are an endless pit that keeps generating inspiration out of thin air and they don't acknowledge. Africa has been so marginalized for so long that that's extra annoying to a lot of people so they just lash out and say "don't use our stuff". But they should use our stuff and give a mention because everyone is using everyone's stuff. Making hoodies out of aso oke fabric; hoodies came from the US, out of American university culture and I put that in my collection so people are aware of what they are wearing.

None of the designers from either Nigeria and Ghana, are using or intend on using Ankara print in their collections, because, for the most part, the fabric does not communicate what they are trying to achieve creatively. Ogisi indicates that the print was so much a part of her childhood that it is now undesirable to use it for her own collections. 
She says, however, that she supports other designers both on and off the continent who do.

The designers expressed specific geographic markets they hope to target - ones they feel will best understand their aesthetics. Some envision opportunities for their brand in Japan, while for others it is South Africa, the US, or the UK. These target markets are based on an understanding of global fashion and culture to which they have been exposed. Unfortunately, many feel this awareness and understanding of country specific trends and culture is not reciprocated of Nigerian life. Oke-Lawal says that it is time for the Western world to look toward Africa:

I feel that people just need to open up their minds and focus not on Ankara -- on the clichés and the wrong stereotypical versions of what Nigeria and Africa is about. Just enjoy the stories and wear the pieces and connect yourself to the stories in the way we do. Nigerians are very aware of what is going on outside of Nigeria. We know what's happening in North America... So I feel like, open up yourselves. Knowledge is power so educate yourselves and wear the clothes and be part of what Africa is becoming. 


\section{Conclusion}

The Western and European fashion world has periodically turned its gaze to the African continent, whether as a source of inspiration, or as an opportunity to feature titillating designs by select designers. It is not enough for the West to allude to an entire continent by borrowing or appropriating unreferenced traditions or to re-visit the same designers for publications, which inherently limits the exposure of products and diversity that prevails across African countries. Further, it may be that the topic of appropriation needs an update for the current context in which entrepreneurs operate, one which appreciates the ingenuity and acumen of those adding to a growing body of contemporary fashion and cultural meaning.

Ghanaian and Nigerian fashion entrepreneurs are creating highly diverse and unique collections that cannot be summarized simply as African fashion. Fashion from the continent does, however, offer clothing options, unlike those available in North American or Europe. The distinctions vary across countries and across cities and are evidenced in the use of hand-woven batakari for skirts (Raffia Clothing) to kaftans made with adire (JZO), to deconstructed secondhand clothing (Hazza Underrated). Designers say they feel it is an exciting time for emerging entrepreneurs in Ghana and Nigeria. They sense a keen desire from those on the continent to wear African-made fashion, as well as a greater interest in their work beyond the continent's borders. For residents of North America, however, access to these growing brands is limited in terms of local retail availability and media coverage. There is an abundance of fashion related web content, but unless consumers in the West are willing to research outside of the familiar, it is all too easy not to be exposed to African brands. As Adebayo Oke-Lawal asserted, Africa has long been familiar with politics and culture in the rest of the world - it is time for the rest of the world to turn towards Africa, to become informed and to buy what is African-made.

Having grown up in Ghana or Nigeria, the designers have witnessed a significant change in the fashion landscape in the last 5 years. These changes include an increased number of fashion events promoting and showcasing designs continent-wide, an increased number of industry personnel from photographers to stylists to bloggers as well as more 
and more individuals who are studying abroad and returning home to launch their brands. These changes that have taken place work in direct opposition to how African fashion is sometimes perceived: traditional, unchanging and fixed. This stereotype - what Homi Bhabha calls fixity - has been falsified even in the context of historic dress by scholars including Joanne B Eicher, Karen Hansen and Victoria Rovine. Many designers are using artisanal techniques like fabric weaving and dying and channeling their own aesthetics, interpretations and understanding of the industry in which they will sell.

The path to success for new fashion brands is not easy. Many in West Africa are running their fashion businesses under inhospitable structural conditions. These conditions are not only the result of the developing economic status from which they are emerging, but cultural representations, media portrayal and unfair appropriative habits of the Western fashion industry. While West African designers navigate the output of their garments and accessories that meet industry standards and legitimize their brand's viability to an international audience through social media and web presence, it is clear that obstacles remain. Investment is needed in order to help standardize production across fashion labels so that each one is positioned to succeed from the outset. Despite a period of positive economic outlook across the continent and the availability of small pools of funding options for those growing a fashion business, increased financing in infrastructure and better channels for distribution are vital for the longevity and upward mobility of the fashion sector on the African continent.

In West Africa and beyond, designers spend months conjuring up fashion lines, season upon season, presenting articles of clothing that are a direct result of nuanced experience, personal identity and cultural meaning. These finished products, diverse as they may be, are part of an exciting yet unforgiving and competitive industry where sales will dictate their success as a brand. Operating within an unequal playing field naturally adds to the risks and liabilities for those entering the industry in West Africa. The designers who took part in this research expressed some of their frustrations from supply chain issues to power cuts. However, it is clear that they feel they are part of a generation of entrepreneurs who are leading West Africa's charge as viable competitors in global fashion production. As Tunde Owolabi, Adebayo Oke-Lawal and Joseph O. Ike discussed, it is important that investment be made not only in industry but in buying from 
entrepreneurs who will help perpetuate economic growth and skill-based labour within their local economy. At present, a number of supportive networks are in place to promote the growth of fashion production in Africa including the African Fashion Guide and Ethical Fashion Initiative, that facilitate knowledge sharing and promotion of designers. These platforms support meaningful employment and industry growth rather than charity - this approach of "trade not aid" is also one that is supported by the United Nations. Foreign investment is important in the growth of Africa's economy and evidence of foreign multinationals moving production to Africa speaks to a changing landscape in fashion manufacturing. That said, as the number of African-based garment factories continues to grow, it is only equitable that Africa sees an increase in the number of successful African-based brands too. The real identifier of positive economic growth in West African fashion will be the industry's ability to support the growing number of entrepreneurs entering the field. 


\section{Acknowledgements}

I would first like to thank my MRP supervisor, Dr. Irene Gammel. I am deeply thankful for her engagement, guidance and helpful comments and feedback at every turn. I would also like to thank my second reader, Dr. Alison Matthews David, for her continued support and interest throughout the program. Furthermore, I thank my supervisor from the University of Ghana, Dr. Akosua Darkwah for her time and assistance while I navigated my way through Ghana.

I am also grateful to the Modern Literature and Culture Research Centre (MLC) and the Department of Fashion for generous support of my travels to Ghana and Nigeria to conduct the onsite research and interviews underpinning this essay, as well as travels to

present the findings at the International African Fashion Guide Conference on May $25^{\text {th }}$ and $26^{\text {th }} 2017$ in London, England.

My most heartfelt thanks go to all of the fashion entrepreneurs I interviewed, for lending me their time and for sharing invaluable insights into their business and the fashion industries of which they are part. I dedicate this work to you!

\section{Ghana}

Afriyie-Kumi, Akosua

Dzidzienyo, Klekleli

Iddriss, Hassan Alfaziz

Kendona, Madonna

Manfreda, Stefania

Osei, Nana K. Osei and Nana Boateng

\section{Nigeria}

Egele, Uchechi

Ike, Joseph O. \& Akindeinde, Ola

Ogisi, Oritsegbubemi (Bubu)

Oke-Lawal, Adebayo

Otitoju, Kunmi

Owolabi, Tunde

Thank you also to fashion blogger Ifeanyi Okafor, Lagos, who was not formally interviewed but provided some helpful background information. 


\section{APPENDIX A}

\section{INTERVIEW OUTLINE - APPROVED BY RYERSON UNIVERSITY ETHICS BOARD, JULY $19^{\text {th }}, 2016$.}

1. When did you start your business?

2. How many people are actively involved in running your business?

3. How would you describe your designs and your target market?

4. Describe the clothes you tend to wear and where they come from.

5. Do you feel your company has a brand identity or identities? And, if so, has the identity of your business evolved since its inception?

6. Describe what techniques you use in your designs. Which of these can you locate as being specific to a local context?

7. Would you ever use Ankara print in your designs? What do you think about its use in contemporary fashion?

8. Tell me about the influence of place in your designs. Do the cities of Lagos/ Accra influence your work? If so, how?

9. What countries/cities do you sell to and what is your largest market?

10. Have there been any challenges you faced in the start-up phases of your company? If so, tell me about what they were and if/ how you overcame them?

11. Are there any current challenges you face in running your business?

12. What role does infrastructure play in your operations as a business? How do issues related to access to electricity, transportation or the Internet impact your ability to conduct business?

13. Do you feel supported by other actors (government, private sector) in starting your company? Why or why not?

14. Describe your impressions about the fashion industry in general since you've started your company. Do you feel the climate has become better, worse or about the same? Why or why not?

15. What (if any) influences do you draw upon from outside your local context? If so, where do these influences come from? Why do you draw upon them?

16. (If they have entered international markets) Why did you choose to sell in (location outside of country) over another?

17. Do you think your designs are more economically successful abroad or in local markets? Why do you think that is?

18. Where do you see the greatest opportunities for your products?

19. Do you sell your products more locally or internationally? Where do you want to be selling your products in the future?

20. (If they sell abroad) Describe how you sell your goods on international markets. Have you faced any challenges in selling your products internationally?

21. What insights can you share about customers in various markets?

22. Do you market your products differently in different marketplaces? Describe any differences from a marketing or advertising perspective.

23. Are you satisfied with the production processes you currently use in making your goods? Would you change them in the future? Why or why not? 


\section{Works Cited}

African Economic Outlook: Sustainable Cities and Structural Transformation. Rep. 15th ed. Paris: OECD, 2016. Web. 19 Jan. 2017.

African Growth and Opportunity Act. Tralac, n.d. Web. 19 Jan. 2017.

Akinwumi, Tunde M. "The 'African Print' Hoax: Machine Produced Textiles Jeopardize African Print Authenticity." Journal of Pan African Studies 2.5 (2008): 179-92. Web. 19 Feb. 2016.

Akinwumi, Tunde M. "The European "African Print" and the Direction of Authentic African Print Design Efforts in Nigeria." Journal of Cultural Studies 8.2 (2010): 300-18. Web. 19 Feb. 2016.

Akinwumi, Tunde M., and Elisha Renne. "Commemorative Textiles and Anglican Church History in Ondo, Nigeria." Textile: The Journal of Cloth and Culture 6.2 (2008): 126-44. Web. 25 May. 2016.

Akudinobi, Jude. "Nollywood: Prisms and Paradigms." Cinema Journal, vol. 54, no. 2, 2015., pp. 133-150doi:10.1353/cj.2015.0008. Web. Jan. 8. 2017.

Aliyu, Abubakar S., Ahmad T. Ramli, and Muneer A. Saleh. "Nigeria Electricity Crisis: Power Generation Capacity Expansion and Environmental Ramifications." Energy, vol. 61, 2013, pp. 354-367, doi:10.1016/j.energy.2013.09.011.

Allman, Jean M. Fashioning Africa: Power and the Politics of Dress. Indiana UP, 2004. Print.

Amekudzi, Leonard K., et al. "Variabilities in Rainfall Onset, Cessation and Length of Rainy Season for the various Agro-Ecological Zones of Ghana." Climate, vol. 3, no. 2, 2015, pp. 416-434, doi:10.3390/cli3020416.

Attanasso, Marie O., Elizabeth Omoluabi, and Olabisi I. Aina. "Gender in Nigeria's Development Discourse: Relevance of Gender Statistics." Étude de la Population Africaine/African Population Studies, vol. 27, no. 2, 2014, pp. 372-385, doi:10.11564/27-2-482.

Balakrishnan, Sarah. Pan-African Legacies, Afropolitan Futures: A Conversation with Achille Mbembe. Bloomington: Indiana UP, 2016, doi:10.2979/transition.120.1.04. Web. 14 Mar. 2017. 
Bawa, Sylvia, and Francis Sanyare. "Women's Participation and Representation in Politics: Perspectives from Ghana." International Journal of Public Administration 36.4 (2013): 282-291. Web. 16 May. 2016.

Berg, S. “Snowball Sampling-I”. Encyclopedia of Statistical Sciences. 12. 2006. Web. 28 May. 2016.

Brooks, Andrew, and David Simon. "Unravelling the Relationships between usedClothing Imports and the Decline of African Clothing Industries: African Clothing Industries and used-Clothing Imports." Development and Change, vol. 43, no. 6, 2012., pp. 1265-1290doi:10.1111/j.1467-7660.2012.01797.x. Web. 18 Jan. 2017.

Creative Economy: A Feasible Development Option. UNCTAD, UNDP, n.d. Web. 19 Jan. 2017.

Delhaye, Christine, and Rhoda Woets. "The Commodification of Ethnicity: Vlisco Fabrics and Wax Cloth Fashion in Ghana." International Journal of Fashion Studies 2.1 (2015): 77-97. Web. 19 Feb. 2016.

Domeisen, Natalie. "Why is the United Nations Working in Fashion?" International Trade Forum, no. 3, 2006. pp. 13. Accessed Jan 82017.

Falola, Toyin, and Matthew M. Heaton. A History of Nigeria. Cambridge: Cambridge UP, 2008. Web. 16 May 2016.

Farber, Leora. "Africanising Hybridity? Toward an Afropolitan Aesthetic in Contemporary South African Fashion Design." Critical Arts 24.1 (2010): 128-67. Web. 19 Feb. 2016.

Fiss, Karen. "Design in a Global Context: Envisioning Postcolonial and Transnational Possibilities." Design Issues 25.3 (2009): 3-10. Web. 28 May 2015.

Florida, Richard L. The Rise of the Creative Class, Revisited, Basic Books, 2012. Frazer, Garth. "Used-Clothing Donations and Apparel Production in Africa." The Economic Journal 118.532 (2008): 1764-84. Web. 27 May 2016.

Gehrmann, Susanne. "Cosmopolitanism with African Roots. Afropolitanism's Ambivalent Mobilities." Journal of African Cultural Studies, vol. 28, no. 1, 2016, pp. 61-72, doi:10.1080/13696815.2015.1112770. Web. 14 Mar. 2017.

Gott, Edith Suzanne, and Kristyne Loughran. Contemporary African Fashion. 
Bloomington: Indiana UP, 2010. Print.

no. 7, 2013., pp. 572-572doi:10.1093/jiplp/jpt091. Accessed Jan. 42017.

"How Verse 2.0 Is Changing the Climate for Emerging African Fashion

Designers." Superselected. n.p. 5 Jan 2016. Web. 16 May 2016.

Hansen, Karen Tranberg, and D. Soyini Madison. African Dress: Fashion, Agency,

Performance. London: Bloomsbury Academic, 2013. Print.

Harris, Colette. "Masculinities and Religion in Kaduna, NigeriAW: A Struggle for

Continuity at a Time of Change." Religion and Gender, vol. 2, no. 2, 2012, pp. 207-230, doi:10.18352/rg.7204.

Immerwahr, Daniel. "The Politics of Architecture and Urbanism in Postcolonial Lagos, 1960-1986." Journal of African Cultural Studies 19.2 (2007): 165-86. Web. 16 May. 2016.

Jennings, Helen. "A Brief History of African Fashion." Journal Of Contemporary African Art 2015.37 (2015): 44-53. Web. 19 Feb. 2016.

Jennings, Helen. New African Fashion. New York: Prestel, 2011. Print.

Johnson, Rachel. "'the Girl about Town': Discussions of Modernity and Female Youth in Drum Magazine, 1951-1970." Social Dynamics, vol. 35, no. 1, 2009., pp. 36doi:10.1080/02533950802666899. Web. 2 Jan. 2016.

Keane, Jodie, and Dirk Willem Te Velde. "The Role of Textile and Clothing Industries in Growth and Development Strategies." Investment and Growth Programme (2008): 1-72. Overseas Development Institute. Web. 14 Mar. 2017.

Konadu, Kwasi, and Clifton C. Campbell. The Ghana Reader: History, Culture, Politics. Durham: Duke UP, 2016. Web. 16 May 2017.

Kozlowski, Anika, Michal Bardecki, and Cory Searcy. "Environmental Impacts in the Fashion Industry." Journal of Corporate Citizenship, vol. 2012, no. 45, 2012, pp. 16-36, doi:10.9774/GLEAF.4700.2012.sp.00004. Web. 12 Mar. 2017.

Kusimi, John M. "Assessing Land use and Land Cover Change in the Wassa West District of Ghana using Remote Sensing." GeoJournal, vol. 71, no. 4, 2008, pp. 249-259, doi: 10.1007/s10708-008-9172-6. Web. 10 March 2017.

Kunz, Grace I., Elena Karpova, and Myrna B. Garner. Going Global: The Textile and Apparel Industry. Fairchild Books, 2016. Print. 
Lewis, Van Dyk. "Dilemmas in African Diaspora Fashion." Fashion Theory: The Journal of Dress, Body \& Culture 7.2 (2003): 163-90. Web. 18 Feb. 2016.

Lobato, Ramon. "Creative Industries and Informal Economies: Lessons from Nollywood." International Journal of Cultural Studies, vol. 13, no. 4, 2010, pp. 337-354, doi:10.1177/1367877910369971.

Lowe, Lisa. The Intimacies of Four Continents. Durham: Duke UP, 2015. Print.

MacLean, Lauren M. "Citizen Or Client? An Analysis of Everyday Politics in Ghana." African Studies Quarterly 15.1 (2014): 93-124. Web. 16 May. 2016.

McCaskie, T. C. "The Life and Afterlife of Yaa Asantewaa." Africa, vol. 77, no. 2, 2007, pp. 151-179, doi:10.3366/afr.2007.77.2.151. Web. 6 April. 2017.

Murillo, Bianca. "'The Modern Shopping Experience': Kingsway Department Store and Consumer Politics in Ghana." AfricAW: The Journal of the International African Institute 82.3 (2012): 368-92. Web. 16 May. 2016.

Nwaolikpe, Onyinyechi Nancy. "Culture and Nigerian Identity in the Print Media." Arabian Journal of Business and Management Review 3.3 (2013): 63. Web. 16 May 2016.

Oh, Erick. "Nigeria's Film Industry: Nollywood Looks to Expand Globally." United States International Trade Commission (USITC) Executive Briefings on Trade (2014): n. Oct. 2014. Accessed 8 Jan. 2017.

Onuoha, Godwin. "A 'rising Africa' in a Resource-Rich Context: Change, Continuity and Implications for Development." Current Sociology, vol. 64, no. 2, 2016; 2015; pp. 277-292doi:10.1177/0011392115614789. Web. Jan 4. 2017.

Pool, Hannah Azieb. Fashion Cities Africa. Bristol: Intellect, 2016. Print.

Quartey, Peter. "Issues in SME Development in Ghana and South Africa." International Research Journal of Finance and Economics 39 (2015): 218-228. Web. 22 Jan. 2017.

Rabine, Leslie W. The Global Circulation of African Fashion: Dress, Body, Culture. Oxford: Berg, 2002. Web. 19 Feb. 2016.

Ray, Carina. "Oxford Street, Accra: Rethinking the Roots of Cosmopolitanism from an Africanist Historian's Perspective." PMLA, vol. 131, no. 2, 2016, pp. 505-514, doi:10.1632/pmla.2016.131.2.505. Web. 13 March 2017. 
Resnick, Danielle. "The Political Economy of Africa's Emergent Middle Class:

Retrospect and Prospects." Journal of International Development, vol. 27, no. 5, 2015. pp. 573-587. doi:10.1002/jid.3110. Web. 19 Jan. 2017.

Richards, Christopher. “'The Models for Africa': Accra's Independence-Era Fashion Culture and the Creations of Chez Julie." African Arts, vol. 49, no. 3, 2016. pp. 821doi:10.1162/AFAR_a_00296. Web. 14 Dec. 2016.

Rogerson, Christian M. "Developing the Fashion Industry in Africa: The Case of Johannesburg." Urban Forum 17.3 (2006): 215-40. 24 May 2016.

Rovine, Victoria L. "Colonialism's Clothing: Africa, France, and the Deployment of Fashion." Design Issues 25.3 (2009): 44-61. Web. 19 Feb. 2016.

Rovine, Victoria L. African Fashion, Global Style: Histories, Innovations, and Ideas You Can Wear. Bloomington: Indiana UP, 2015. Print.

Said, Edward W. Culture and Imperialism. New York: Knopf, 1993. Print.

Schroeder, Jonathan E., Miriam Salzer-Mörling, and Sren Askegaard. Brand Culture. London: Routledge, 2006. Web. 28 May 2016.

Schneider, M. "Africa Rising." Journal of Intellectual Property Law \& Practice, vol. 8, Obeng-Odoom, Franklin. "An Urban Twist to Politics in Ghana." Habitat International 34.4 (2010): 392-9. Web. 16 May. 2016.

Selasi, Taiye. "Bye-Bye Barbar." The LIP Magazine. N.p., 3 Mar. 2005. Web. 14 Mar. 2017.

Smallbone, David. "Foreign Direct Investment and SME Development: Some Policy Issues for Transition and Developing Countries." Entrepreneurship in United Europe: Challenges and Opportunities (2006): 13-17. 22 Jan. 2017.

Spring, Christopher. African Textiles Today. London: British Museum, 2012. Print.

"World Economic Outlook: Sub-SaharanAfrica Multispeed Growth." Rep. Washington: International Monetary Fund, 2016. Web. 19 Jan. 2017. 


\section{Notes (newspapers/blogs)}

Akwagyiram, Alexis. "Made in Africa: Is Manufacturing Taking off on the Continent?" BBC News 29 May 2014. Web. 16 May. 2016.

'Africa Rising: The hopeful continent', The Economist, 3 December 2011. Available at: www. economist.com/node/21541015. Web. Jan 4. 2017.

'Africa: There is hope', The Economist, 9 October 2008. Available at: www.economist.com/ node/12381162. Web. Jan4. 2017.

Berg, Achim, Saskia Hedrich, and Bill Russo. "East Africa: The next Hub for Apparel Sourcing?" McKinsey \& Company, Aug. 2015. Web. 06 Apr. 2017.

Ellis, Kristi. "Africa Emerging as Next Frontier." WWD, vol. 208, no. 5, 2014., pp. 12. Web. 19 January. 2017.

"Elle Lokko." Time Out Accra. Time Out Print \& Digital Publishing, 03 Jan. 2017. Web. 14 Mar. 2017.

"Ghana." The World Bank. The World Bank Group, n.d. Web. 15 Mar. 2017. Ghana Meteorological Agency. GMET, n.d. Web. 15 Mar. 2017.

Kwateng-Clark, Danielle. "12 Ghanaian Designers to Know." Teen Vogue. Conde Nast, 26 Dec. 2016. Web. 14 Mar. 2017.

Lagos, Monica M. "Why Not Lagos? Fashion Week Triumph Sees Africa's Star Rising." The Guardian UK, 2012, pp. 19. Web. 19 January. 2017.

Lobrano, Alexander. "Africa's Capital of Cool." The New York Times. The New York Times, 12 July 2016. Web. 14 Mar. 2017. 